Campbell University School of Law

Scholarly Repository @ Campbell University School of Law

2018

\title{
Is It Bad Law To Believe A Politician? Campaign Speech and Discriminatory Intent
}

Shawn E. Fields

Campbell University School of Law, sfields@campbell.edu

Follow this and additional works at: https://scholarship.law.campbell.edu/fac_sw

Part of the First Amendment Commons, and the Fourteenth Amendment Commons

\section{Recommended Citation}

Shawn E. Fields, Is It Bad Law To Believe A Politician? Campaign Speech and Discriminatory Intent, $52 \mathrm{U}$. Rich. L. Rev. 273 (2018).

Available at: https://scholarship.law.campbell.edu/fac_sw/152

This Article is brought to you for free and open access by the Faculty Scholarship at Scholarly Repository @ Campbell University School of Law. It has been accepted for inclusion in Scholarly Works by an authorized administrator of Scholarly Repository @ Campbell University School of Law. 


\title{
ARTICLES
}

\section{IS IT BAD LAW TO BELIEVE A POLITICIAN? CAMPAIGN SPEECH AND DISCRIMINATORY INTENT}

\author{
Shawn E. Fields *
}

"Candidates say many things on the campaign trail; they are often contradictory or inflammatory. No shortage of dark purpose can be found by sifting through the daily promises of a drowning candidate, when in truth the poor shlub's only intention is to get elected."1

"If you ever injected truth into politics you have no politics."

\section{INTRODUCTION}

Politicians lie. For better or worse, we have grown accustomed to this unsavory practice. We expect candidates for public office to make promises they have no intention of keeping. We expect candidates to say one thing to "play to the base" during primaries, only to contradict themselves as they "play to the middle" in the general election. ${ }^{3}$ But should this unfortunate fact of political discourse influence judicial analysis of a politician's potentially unconstitutional motivations behind a challenged government action? Should courts refuse even to consider discriminatory and

* Professor of Legal Writing, University of San Diego School of Law; Professor of Political Science, Point Loma Nazarene University. I would like to thank my research assistant, Gwenllian Kern-Allely, for her invaluable contributions to this article.

1. Washington v. Trump, 858 F.3d 1168, 1173 (9th Cir. 2017) (Kozinski, J., dissenting).

2. Will Rogers, Will Rogers on Politics, WILL ROGERS TODAY, http://www.willrogers today.com/will_rogers_quotes/quotes.cfm?9ID=4 (last visited Nov. 15, 2017).

3. See Marina Agranov, Flip-Flopping, Primary Visibility, and the Selection of Candidates, 8 AM. ECON. J. 61, 67-72 (2016). 
inflammatory campaign pledges in assessing the purpose of a statute or regulation simply because we distrust our elected officials? Can such a bright-line evidentiary exclusion be justified even when a political candidate speaks openly, consistently, and convincingly about his desire to enact impermissibly discriminatory policies if elected? ${ }^{4}$

Courts across the country are currently facing these questions as they consider whether and to what extent then-candidate Donald Trump's incendiary comments about Muslims suggest that President Trump's executive orders on immigration were motivated by impermissible religious animus. ${ }^{5}$ As with discriminatory intent case law generally, courts have applied inconsistent and contradictory evidentiary frameworks to evaluate President Trump's campaign statements. ${ }^{6}$ Lacking a coherent judicial doctrine to govern them, courts are left to advance conflicting policy rationales for how the campaign statements of a private citizen ought to or ought not to be considered as evidence of official government discriminatory intent. ${ }^{7}$

Surprisingly little has been written about the proper role of campaign rhetoric in the subjective motive analyses of the First and Fourteenth Amendments. ${ }^{8}$ This article seeks to fill that gap

4. Matthew Segal, President Trump's Campaign Promises Stick With Us-They Should Stick With Him, Too, JUST SECURITY (Mar. 25, 2017, 9:02 AM), https://www.justse curity.org/39246/president-trumps-campaign-promises-stick-us-they-stick-him/ ("Given the Trump Administration's many anti-Muslim statements, it's hard to imagine how the ban could be upheld by any court that gives serious weight to that evidence.").

5. 'Trump v. Int'l Refugee Assistance Project, 582 U.S. _, 137 S. Ct. 2080 (2017); Int'l Refugee Assistance Project v. Trump, 857 F.3d 622 (4th Cir. 2017); Washington v. Trump, No. C17-0141JLR, 2017 U.S. Dist. LEXIS 16012, at *1 (W.D. Wash. Feb. 3, 2017).

6. See Int'l Refugee, 857 F.3d at 598-99 ("[The U.S. Court of Appeals for the Fourth Circuit] decline[s] to impose a bright-line rule against considering campaign statements, because as with any evidence, [the court] must make an individualized determination as to a statement's relevancy and probative value in light of all the circumstances."); Washington v. Trump, 858 F.3d at 1174 (Kozinski, J., dissenting) ("Even if a politician's past statements were utterly clear and consistent, using them to yield a specific constitutional violation would suggest an absurd result-namely, that the policies of an elected official can be forever held hostage by the unguarded declarations of a candidate."); Hawaii v. Trump, 859 F.3d 741, 761 (9th Cir. 2017) (noting the findings of the lower court that "the historical record ... contained 'significant and unrebutted evidence of religious animus driving the promulgation of the Executive Order,"' but declining to discuss whether such pre-election campaign evidence should be considered, instead affirming the lower court's injunction on statutory grounds).

7. See supra note 6.

8. Cf. Michael A. Collata, The Role of Circumstantial Evidence in Proving Discriminatory Intent: Developments Since Washington v. Davis, 19 B.C.L. REV. 795, 800-01 (1978) (exploring use of circumstantial evidence generally to determine discriminatory intent, 
by addressing the competing policy rationales currently articulated across the country. In doing so, this article will consider the spectrum of opinions offered in connection with the ubiquitous travel ban litigations. ${ }^{9}$ On one end of the spectrum, conservative Ninth Circuit judges Jay Bybee and Alex Kozinski have eschewed precedent to suggest that review of the constitutionality of any government action should be limited to the four corners of the document and that judges should refrain from peeking "behind the curtain" of the official action to divine intent. ${ }^{10} \mathrm{On}$ the other end of the spectrum, a majority of judges in the Fourth Circuit Court of Appeals have intimated that all sorts of extra-official evidence can form the "relevant context" for discriminatory intent purposes, including campaign statements. ${ }^{11}$ This expansive position begs the question: "Does the relevant context include everything the Trump Administration has said?"12 This article will also address the misguided but increasingly proffered claim by Jeffrey Toobin and others that a government action "is either constitutional or it's not" regardless of the intent behind the action. ${ }^{13}$

which may include campaign speech); Thomas B. Henson, Note, Proving Discriminatory Intent from a Facially Neutral Decision with a Disproportionate Impact, 36 WASH. \& LEE L. REV. 109, 112 (1979) (critiquing specific intent requirement and narrow categories of evidence available to prove specific intent); Sofia D. Martos, Coded Codes: Discriminatory Intent, Modern Political Mobilization, and Local Immigration Ordinances, 85 N.Y.U. L. REV. 2099, 2100-04 (2010) (asserting role for more rigorous application of the Davis and Arlington Heights six-factor test to extra-official communications to detect discriminatory intent, but not addressing campaign speech specifically).

9. See, e.g., Int'l Refugee, 857 F.3d at 594 ("Then-candidate Trump's campaign statements reveal that on numerous occasions, he expressed anti-Muslim sentiment, as well as his intent, if elected, to ban Muslims from the United States."); see David S. Rubenstein \& Pratheepan Gulasekaram, Immigration Exceptionalism, 111 Nw. L. REV. 583, 585 n.6 (2017) (listing the growing number of litigations and declaring that "[ $t$ ]he litigation over President Trump's executive order is sprawling").

10. Washington v. Trump, 858 F.3d at 1183 (Bybee, J., dissenting) ("[]f we have questions about the basis for the President's ultimate findings," courts cannot "peek behind the curtain," even if it is to determine whether the Executive Order is a "Muslim ban' or something else.").

11. Int'l Refugee, 857 F.3d at 598-99 ("[T] Ge Government argues that even if we could consider unofficial acts and statements, we should not rely on campaign statements. . . But we decline to impose a bright-line rule against considering campaign statements, because as with any evidence, we must make an individualized determination as to a statement's relevancy and probative value in light of all the circumstances.").

12. Segal, supra note 4 .

13. Jeffrey Toobin, The Courts and President Trump's Words, NEw YoRKER (Mar. 17, 2017), http://www.newyorker.com/news/daily-comment/the-courts-and-president-trumpswords ("The Muslim ban is either constitutional or it's not-and Donald Trump's words on the campaign trail don't settle that question one way or the other."). 
Ultimately, this article asserts that any bright-line rules rejecting consideration of campaign statements or other extra-official evidence cannot be justified as a matter of law or logic. Instead, the inquiry over whether and how to consider campaign statements in the discriminatory intent analysis ought to be factspecific, flexible, and guided by traditional notions of evidence, with an emphasis on evidentiary weight over evidentiary admissibility.

This article proceeds in three parts. First, it outlines the contours of discriminatory intent analysis in the First and Fourteenth Amendment contexts, beginning with Washington v. Davis and continuing through the travel ban litigations. This background highlights the consistent reluctance of courts to consider extrinsic evidence of discriminatory intent even in the most egregious circumstances. Second, this article examines the "peculiar" case of campaign speech as a form of extrinsic evidence of discriminatory intent and systematically refutes the five major arguments advanced in favor of a per se ban on consideration of campaign speech. ${ }^{14}$ In short, these arguments all articulate concerns over the evidentiary reliability of such statements, concerns which can and should be handled by courts discounting the weight of such evidence where necessary, not by blindly refusing to admit the evidence at all. Third, this article reflects on objective considerations that may assist courts in assessing the probative value of campaign speech, including the size of the decisionmaking body, the nature of the constitutional claim, and any special deference or separation of powers concerns implicated by immigration or foreign policy actions. While these factors will likely always be relevant in the context of a discriminatory intent analysis, their application to campaign speech specifically can help bring clarity to a confused area of constitutional jurisprudence.

This article concludes with an observation that a restrictive, bright-line rule preventing the admissibility of campaign statements neither adheres to the letter nor spirit of Washington $v$. Davis and its progeny, nor provides the "manageable, sensible" solution its proponents claim. ${ }^{15}$ Moreover, this artificial barrier

14. See Washington v. Trump, 858 F.3d at 1173-74 (Kozinski, J., dissenting).

15. See id. at 1174 ("Limiting the evidentiary universe to activities undertaken while crafting an official policy makes for a manageable, sensible inquiry."). 
ignores the paramount importance of uncovering discriminatory government animus and the near-insurmountable hurdles already facing plaintiffs charged with proving animus. By retaining flexibility to consider the probative value of campaign statements on a case-by-case basis, courts can protect the traditional role of the fact-finder, preserve the viability of constitutional civil liberties cases, and hold politicians to account for the promises and pledges on which their voters rely.

\section{AN OVERVIEW OF DISCRIMINATORY INTENT ANALYSIS}

Under well-settled United States Supreme Court precedent, the constitutionality of a given action often depends on the government's motive; the same exact action can be constitutional or unconstitutional depending on the reason why the government is doing what it is doing. ${ }^{16}$ But this centrality of discriminatory motive to First and Fourteenth Amendment constitutional challenges occurred during the seismic jurisprudential shift from the Warren era to the Burger Court era, and the Court's attempts to refine discriminatory intent analysis since that time have been at times halting, contradictory, and "confused."17

A defining characteristic of the Warren Court of the 1950s and 1960 s was its sympathetic view towards civil rights litigation, including its expansive approach to challenges to state action pursuant to the Equal Protection Clause. ${ }^{18}$ Indicative of this sympathy was the Warren Court's willingness to strike down facially neutral government regulations as unconstitutional if those regulations had a sufficiently discriminatory impact on a discrete ra-

16. McCreary Cty, v. ACLU of Ky., 545 U.S. 844, 866 n.14 (2005) ("One consequence of taking account of the purpose underlying past actions is that the same government action may be constitutional if taken in the first instance and unconstitutional if it has a sectarian heritage.").

17. Vikram D. Amar \& Alan E. Brownstein, The Complexities of a "Motive" Analysis in Challenging President Trump's Executive Order Regarding Entry to the United States, VERDICT (Mar. 24, 2017), https://verdict.justia.com/2017/03/24/complexities-motive-analy sis-challenging-president-trumps-executive-order-regarding-entry-united-states ("Consideration of direct evidence of impermissible subjective motive has been a confused area of constitutional law.").

18. Gregory Dickinson, One Justice, Two Justice, Red Justice, Blue Justice: Dissecting the Role of Political Ideology in Supreme Court Nominations, 2017 U. ILL. L. REV. 345, 354 (2017) ("Today, the Warren Court is known for its liberal majority that expanded civil rights, civil liberties, and judicial power. During the late 1950 s and early 1960 s, the Court handed down many well-known civil-rights decisions."). 
cial group or other protected class. ${ }^{19}$ This impact approach rested on objective empirical evidence and sidestepped the thorny issue of divining a legislative body's intent behind an action. ${ }^{20}$

In contrast, the Burger Court of the 1970s was defined as much by its reactionary curtailment of Warren Court era civil rights protection as by any affirmative jurisprudential mark left during the decade. ${ }^{21}$ This philosophically more restrictive view of equal protection expressed itself most notably in the 1976 case Washington $v$. Davis, which held that courts may not invalidate facially neutral statutes solely because of their discriminatory effect. ${ }^{22}$ Instead, courts can invalidate a government action as violative of the Equal Protection Clause only if the action was motivated by an intention to discriminate against a protected group. ${ }^{23}$ While Davis and its progeny confirmed that objective impact analysis remained relevant, the primary evidentiary concern of courts faced with an Equal Protection Clause challenge would be the

19. See Jim Chen, Come Back to the Nickel and Five: Tracing the Warren Court's Pursuit of Equal Justice Under Law, 59 WASH. \& LEE L. REV. 1203, 1222-23 (2002) (describing the civil rights legacy of the Warren Court, including the willingness to consider disparate impact of facially neutral legislation); Brian K. Landsberg, Race and the Rehnquist Court, 66 TUL. L. REV. 1267, 1279 (1992) (discussing the Warren Court's introduction of the concept that "racially disparate effects (disparate impact)-use of a device that is facially neutral but has a disproportionate adverse effect on minorities-might reflect unlawful racial discrimination").

20. Paradoxically, the Warren Court also refused to consider evidence of discriminatory motive in circumstances where the disparate impact was nevertheless constitutionally warranted. See United States v. O'Brien, 391 U.S. 367, 370, 372, 383 (1968) (The Court held that criminalizing the practice of burning draft cards was constitutional because the cards were needed to administer the draft, and rejected the argument that the intent of the law was to suppress the ideas that the burning of draft cards communicated: "It is a familiar principle of constitutional law that this Court will not strike down an otherwise constitutional statute on the basis of an alleged illicit legislative motive.").

21. Indeed, the 1968 presidential election featured Richard Nixon running "against the liberal Warren Court almost as much as his actual opponent." THOMAS M. KECK, THE Most ACtivist SuPREme CoURT IN History 4 (Univ. Chicago Press 2004). "When he realized Nixon would be president, Chief Justice Warren immediately announced his retirement in an attempt to allow the lame duck President Lyndon Johnson to replace him." Dickinson, supra note 18, at 355; see Chen, supra note 19, at 1263 ("The Burger Court proved to be the last battleground on which Earl Warren and Richard Nixon played out their heated rivalry.").

22. 426 U.S. 229, 242 (1976) ("Disproportionate impact is not irrelevant, but it is not the sole touchstone of an invidious racial discrimination forbidden by the Constitution. Standing alone, it does not trigger the rule that racial classifications are to be subjected to the strictest scrutiny and are justifiable only by the weightiest of considerations." (citation omitted)).

23. Id. at $239-40,244-45$. 
subjective motivations of the lawmakers enacting the regulation. ${ }^{24}$

This article does not seek to relitigate the wisdom or propriety of the Court's move away from impact and towards intent. That path has been well-worn by scholars for four decades. ${ }^{25}$ Instead, it seeks to briefly sketch the outline of discriminatory intent analysis since Davis to provide context for the debate over whether a politician's campaign statements should factor into this analysis. In doing so, one incontrovertible truth should become clear: divining the subjective motivations behind an action is a much more complicated and problematic endeavor than assessing the objective impact of that action. This fact predictably has persuaded courts to strictly limit the types of evidence they will consider and to refuse to weigh evidence they deem sufficiently unreliable, including campaign statements. ${ }^{26}$ As this section asserts, however, this approach is logically unjustified and legally inconsistent with the intent of Davis and its progeny.

First, this part highlights the analytical framework of intent analysis in Fourteenth Amendment race-based challenges articulated in Davis, Village of Arlington Heights v. Metropolitan Housing Development Corp. ${ }^{27}$ and Personnel Administrator v. Feeney. ${ }^{28}$ Second, it summarizes how this facially broad framework has been limited by lower courts. Third, it explores how this Fourteenth Amendment intent analysis has informed First Amendment religious discrimination cases, which have significant substantive overlap with race-based challenges and which have direct relevance to the cases percolating through the courts considering whether and how to analyze the impact of then-

24. See id. at 243; Martos, supra note 8, at 2103; Michael Selmi, Was the Disparate Impact Theory a Mistake?, 53 UCLA L. REV. 701, 728, 725-32 (2006) (noting changing nature of Equal Protection Clause claims after Davis).

25. See, e.g., Charles Lawrence III, Unconscious Racism Revisited: Reflections on the Impact and Origins of "The Id, the Ego, and Equal Protection," 40 CoNN. L. REv. 931, 94448, 952-55 (2008) (summarizing the development of post-Davis scholarship in disparate impact versus discriminatory intent judicial analysis under the Fourteenth Amendment); Ian F. Haney Lõpez, "A Nation of Minorities": Race, Ethnicity, and Reactionary Colorblindness, 59 STAN. L. REV. 985, 989, 995 n.31 (2007) (challenging the trend towards "colorblindness" in judicial review post-Davis); Selmi, supra note 24, at 705 (defending discriminatory intent analysis).

26. See, e.g., Hamdan v. Rumsfeld, 548 U.S. 557, 623-24 n.52 (2006) (declining to "defer [ to comments made by [government] officials to the media" when determining discriminatory intent because such extraofficial statements are inherently unreliable).

27. 429 U.S. 252,265 (1977).

28. 442 U.S. $256,272(1979)$. 
candidate Trump's statements on the constitutionality of President Trump's actions.

\section{A. The Birth of Discriminatory Intent Analysis: Davis, Arlington Heights, and Feeney}

In Davis, the Court held that discriminatory impact alone was insufficient to prove the existence of impermissible racial classification under the Equal Protection Clause of the Fourteenth Amendment. ${ }^{29}$ The Court found that such an equal protection challenge could withstand judicial scrutiny only if the movant could demonstrate that the intent behind the governmental action was to discriminate on the basis of race. ${ }^{30}$ "That is, a factual finding that a statute imposes a disproportionate burden on a particular racial group is not sufficient to invalidate that statute absent some other indication of a discriminatory purpose for enactment." 31

In Davis, the plaintiffs alleged that a test for a position as a police officer in the District of Columbia violated the Equal Protection Clause because a higher percentage of blacks than whites failed the test. ${ }^{32}$ In rejecting this previously recognized discriminatory impact argument, the Court found that evidence of a correlation between an action and a disproportionately negative effect on a protected class, standing alone, was insufficient to trigger strict scrutiny. ${ }^{33}$ Instead, the Court explained that strict scrutiny of a challenged action under the Equal Protection Clause would be triggered only when a plaintiff provided sufficient evi-

29. Washington v. Davis, 426 U.S. 229, 242 (1976).

30. Id. ("Necessarily, an invidious discriminatory purpose may often be inferred from the totality of the relevant facts, including the fact, if it is true, that the law bears more heavily on one race than another... . Nevertheless, we have not held that a law, neutral on its face and serving ends otherwise within the power of the government to pursue, is invalid under the Equal Protection Clause simply because it may affect a greater proportion of one race than of another.").

31. Julia Kobick, Discriminatory Intent Reconsidered: Folk Concepts of Intentionality and Equal Protection Jurisprudence, 45 HARV. C.R.-C.L. L. REV. 517, 521-22 (2010) ("When plaintiffs challenging a government action or statute cannot prove that it was purposefully discriminatory toward the race in question, courts will uphold the action if it is rationally related to a legitimate government interest. This deferential standard of review works as a presumption of validity of the government action.").

32. Davis, 426 U.S. at 232, 235; see also Kobick, supra note 31, at 522 (noting that the plaintiffs alleged "the test had not been validated as predictive of future job performance" but did not allege "that the test was intentionally discriminatory").

33. Davis, 426 U.S. at 242. 
dence that the intent of the facially neutral action was to discriminate on the basis of race. ${ }^{34}$ While the Court affirmed that the objective "[d]isproportionate impact is not irrelevant," it remained relevant only as a factor in the analysis of whether a subjective discriminatory purpose existed. ${ }^{35}$ By considering the "totality of the relevant facts," including disproportionate impact, courts might be able to infer discriminatory intent. ${ }^{36}$ However, the Court neither expanded on how litigants could prove discriminatory purpose nor what factors it would consider in this "totality of the relevant facts" test. ${ }^{37}$

The Court addressed this ambiguity one year later in Arlington Heights, when it both established a framework for judicial evaluations of discriminatory intent claims and articulated a six-factor test to guide its analysis. ${ }^{38}$ In Arlington Heights, the plaintiffs challenged a municipality's rejection of a petition for rezoning in a wealthy, predominantly white Chicago suburb which would have cleared the way for a low- and moderate-income housing development affirmatively advertised to racial minorities in an attempt at racial integration. ${ }^{39}$ The plaintiffs provided evidence that the government's rejection adversely affected racial minorities and further suggested, pursuant to Davis, that the action was motivated by animus toward these minorities. ${ }^{40}$

In determining how to consider the plaintiffs' evidence of discriminatory intent, the Court established the analytical framework for judicial evaluations of such evidence that continues to govern intent analysis. First, courts are to look to any direct evidence of discriminatory purpose and intent, such as an open discussion in the legislative history that the law was intended to disfavor a racial group. ${ }^{41}$ Where direct evidence is unavailable, as it often is and as it was in Arlington Heights, courts are to make "a

34. Id. at $240,242$.

35. Id.

36. See id.

37. See id.

38. Village of Arlington Heights v. Metro. Hous. Dev. Corp., 429 U.S. 252, 267-68 (1977).

39. See id. at 257 .

40. Id. at $263-65,269$.

41. Id. at 266 ("Sometimes a clear pattern, unexplainable on grounds other than race, emerges from the effect of the state action even when the governing legislation appears neutral on its face. The evidentiary inquiry is then relatively easy. But such cases are rare." (citations omitted)). 
sensitive inquiry into such circumstantial and direct evidence of intent as may be available" and look at the totality of the relevant evidence to determine "whether invidious discriminatory purpose was a motivating factor" for the decision. ${ }^{42}$

To guide this sensitive inquiry, the Court adopted a six-factor test to evaluate evidence of such intent: (1) the discriminatory effect of the official action, (2) the historical background of the decision, (3) the specific sequence of events leading up to the challenged decision, (4) departure from the normal procedural sequence, (5) departure from the normal substantive standard, and (6) legislative or administrative history of the decision. ${ }^{43}$ The Court ultimately rejected the equal protection challenge, finding that, although the official action had a discriminatory effect on racial minorities, the plaintiffs failed to demonstrate the presence of a discriminatory intent because there existed no departure from the normal municipal process nor any historical or legislative evidence of racial animus. ${ }^{44}$

A natural question left unresolved by Arlington Heights was whether and to what extent a decision maker's ability to foresee that a particular action would disproportionately harm minorities could serve as circumstantial evidence of animus. After all, any reasonable official could have foreseen that the rejection of a zoning ordinance designed specifically to increase minority residential presence in an affluent and desirable suburb would naturally have a discriminatory effect on those minorities.

The Court answered that question in Feeney, holding that even if a disparate impact was foreseeable, the constitutional standard for discriminatory intent requires proof that decision makers acted because of this impact, not merely in spite of it. ${ }^{45}$ In Feeney, the

42. See id. at $266-68$.

43. Id. at $267-68$ ("The foregoing summary identifies, without purporting to be exhaustive, subjects of proper inquiry in determining whether racially discriminatory intent existed.").

44. Id. at 269-70. While the Court acknowledged that the "impact of the Village's decision does arguably bear more heavily on racial minorities ... [t] he statements by the Plan Commission and Village Board members, as reflected in the official minutes, focused almost exclusively on the zoning aspects of the MHDC petition." Id.

45. Pers. Adm'r v. Feeney, 442 U.S. 256, 279 (1979) ("Discriminatory purpose ... implies more than intent as volition or intent as awareness of consequences. It implies that the decisionmaker... selected or reaffirmed a particular course of action at least in part 'because of,' not merely 'in spite of,' its adverse effects upon an identifiable group." (citation omitted)). 
plaintiffs alleged that a Massachusetts statute requiring the applications of veterans who qualified for civil service jobs to be considered ahead of all other applications amounted to unconstitutional gender discrimination because the statute operated "overwhelmingly to the advantage of males." 46 Indeed, Justice Stewart acknowledged in his majority opinion that it would be "disingenuous to say that the adverse consequences of this legislation for women were unintended, in the sense that they were not volitional or in the sense that they were not foreseeable." 47

Notwithstanding this acknowledgement, the Court found that generalized intent was insufficient proof of discriminatory purpose, which implied "more than intent as volition or intent as awareness of consequences." 48 Instead, the Court held that the Equal Protection Clause required a more specific intent where the government "selected or reaffirmed a particular course of action at least in part 'because of,' not merely 'in spite of,' its adverse effects upon an identifiable group." 49

This more subjective inquiry into the specific intent of a legislature imposes a significantly more demanding burden of proof on plaintiffs than the more objective Arlington Heights test. ${ }^{50}$ Under Arlington Heights, the presence of evidence satisfying each of the six factors presumably would have been sufficient to demonstrate discriminatory intent and to trigger strict scrutiny. After Feeney, however, a litigant not only must present evidence to satisfy these factors, but must also convince the court that this evidence existed because government officials wanted to discriminate against a protected class. ${ }^{51}$

The practical effect of Feeney has been two-fold. First, in the absence of further guidance regarding how a litigant can prove

46. Id. at 259 .

47. Id. at 278 .

48. Id. at 279 .

49. Id.

50. Sheila Foster, Intent and Incoherence, 72 TUL. L. REV. 1065, 1085 (1998); Kobick, supra note 31 , at $527-28$.

51. See Kobick, supra note 31, at 528 ("Feeney at once left the door open for an inquiry into whether the foreseeability of harm supports an inference of intent and confirmed that foreseeability of harm is not sufficient evidence to find intent to harm. . . While the Court suggested that evidence of foreseeability can support a 'strong inference' of intent, the Court's dicta did not equate foreseeability with the other Arlington Heights factors, and it did not clarify the appropriate role for foreseeability in the context of the totality of the circumstances test."). 
discriminatory intent, courts have largely limited their evaluation of the evidence to official governmental records and refused to consider "unofficial" or "extra-official" evidence of animus. ${ }^{52}$ Second, as a result of the heightened Feeney subjective intent standard and courts' restriction of the Arlington Heights factors to official records, few equal protection challenges survive judicial scrutiny. ${ }^{53}$

\section{B. Discriminatory Intent Analysis After Feeney}

The ambiguity of Davis and its progeny has left "[c]onsideration of direct evidence of impermissible subjective motive ... a confused area of constitutional law." ${ }^{4}$ Faced with this lack of analytical clarity and the inherently difficult task of divining an individual's personal motivations, let alone the motivations of a large legislative body, courts have "often expressed ... a reluctance to use extrinsic proof of invidious motive to strike down laws that would otherwise pass constitutional muster." 55 The current evidentiary inquiry posed by most courts narrowly relies on official governmental records, which rarely contain evidence of discriminatory animus, and ignores other "unofficial" historical evidence. As a result, equal protection challenges rarely succeed.

Two important post-Feeney equal protection cases illustrate this narrow evidentiary approach. In City of Memphis v. Greene, black residents challenged the local government's decision to close a city street, claiming that the closure was a discriminatory attempt to separate the city racially in a way that benefitted the

52. Foster, supra note 50, at 1085 ("Though the Court in Feeney set out to define the meaning of discriminatory purpose . . . adherence to the Feeney conception of intent has been selective. In some cases, the Feeney standard is explicitly invoked and relied upon by the Court. In other cases, this narrow conception of intent is virtually ignored."); see id. at 1086 (noting that the Court in McCleskey $v$. Kemp limited the relevance of unofficial records, such as "historical and statistical evidence to demonstrat[e] a specific discriminatory intent").

53. See, e.g., McCleskey v. Kemp, 481 U.S. 279, 298 (1987) ("For this claim to prevail, McCleskey would have to prove that the Georgia Legislature enacted or maintained the death penalty statute because of an anticipated racially discriminatory effect."); Wayte v. United States, 470 U.S. 598, 610 (1985) ("In the present case, petitioner has not shown that the Government prosecuted him because of his protest activities.").

54. Amar \& Brownstein, supra note 17.

55. Id.; see also Foster, supra note 50, at 1086-93 (discussing incoherence of discriminatory intent analysis post-Feeney and explaining that the Court has alternately required proof of specific government intent to discriminate and inferred discriminatory intent from objective and circumstantial evidence); Kobick, supra note 31 , at 529 (highlighting the "doctrinal incoherence" of the post-Feeney discriminatory intent analysis). 
white community and adversely affected the black community. ${ }^{56}$ In addition to presenting empirical evidence demonstrating the discriminatory effect of the action, the plaintiffs also introduced evidence at trial "in support of the contention that the community activists (demanding closure of the street) were motivated by the desire to limit black vehicular traffic through their neighborhood." 57 The Court disregarded this "unofficial" evidence as irrelevant and focused its evidentiary inquiry solely on official City Council hearing testimony and statements and resolutions by City Council members when making their decision to close the public street. ${ }^{58}$ Not surprisingly, this public record lacked any expression of racial animus, thus ending the inquiry for the Court. ${ }^{59}$

This unwillingness to consider evidence outside the "official record" betrays both the letter and the spirit of the Arlington Heights six-factor test. On its face, these six factors contemplate a broad inquiry into both official governmental processesdepartures from procedural and substantive sequences of legislative decision-making and the legislative and administrative history-as well as extra-governmental context, such as historical background and pre-action sequence of events. ${ }^{60}$ For example, Justice Marshall's dissent in Greene emphasized the larger historical and social context surrounding the City's decision, including Memphis's "unfortunate but very real history of racial segregation." 61 The majority's refusal to consider this larger "historical background" or the "specific sequence of events leading up to the challenged decision," which included vocal demonstrations by ac-

56. 451 U.S. 100, 102 (1981).

57. Gayle Binion, "Intent" and Equal Protection: A Reconsideration, 1983 SUP. CT. REV. 397, 432-33 (1983). "During the brief City Council hearing, residents of the area north of Hein Park presented petitions with approximately 1,000 signatures protesting the closing of West Drive, stating: "This Closing symbolizes in unmistakable terms a White neighborhood shutting its door on its adjacent Black and integrated communities." Greene, 51 U.S. at 143 n.9 (Marshall, J., dissenting).

58. Greene, 451 U.S. at 113-14, 116 (majority opinion) (ignoring statements by city council members and protestors that the closure would protect "the neighborhood from 'undesirable' outside influences ... suggesting that ... the closure [was] motivated by the racial attitude of the residents of Hein Park," and considering only the official City Council statements that it was only "the 'undesirable' character of the traffic flow" with which the government was concerned).

59. Id. at 126 (noting that the official records only included "legitimate" motivations for the closure, including "[p]roper management of the flow of vehicular traffic . . . and the pedestrians' interest in safety").

60. See Village of Arlington Heights v. Metro. Hous. Dev. Corp., 429 U.S. 252, 269-70 (1977).

61. Greene, 451 U.S. at 144 (Marshall, J., dissenting). 
tivist voters demanding the resultant action for race-based reasons, ignores the second and third factors of the Arlington Heights test and unjustifiably truncates the evidentiary inquiry. ${ }^{62}$

Relying on Feeney and Greene, the Eighth Circuit likewise turned a blind eye to damning extra-official evidence of discriminatory intent in Gray v. City of Valley Park. ${ }^{63}$ In Valley Park, the plaintiffs sought to permanently enjoin enforcement of the City's zoning ordinances regulating the presence and employment of illegal aliens. ${ }^{64}$ Among other things, the ordinances penalized landlords who leased to illegal immigrants and employers who employed illegal immigrants. ${ }^{65}$ Though facially neutral, the plaintiffs presented compelling evidence that the ordinances were motivated by discriminatory animus toward Latinos. Plaintiffs submitted evidence of the Mayor's statements in a local newspaper concerning the supposed necessity of the ordinances, including his statement: "You got one guy and his wife that settle down here, have a couple kids, and before long you have Cousin Puerto Rico and Taco Whoever."66 Despite these damning statements, and despite evidence of the Mayor's pivotal role in passing the ordinances, the court nevertheless rejected the equal protection challenge due to a "lack of discussion [of discriminatory intent] during the meeting at which the Ordinance was passed." 67

62. Id. at 141-42, 141 n.5 (quoting Arlington Heights, 429 U.S. at 252) (Official statements by the City Council are "not, as the majority implies, the only Arlington Heights type evidence produced as trial. The testimony of city planning officials, for example, strongly suggests that the city deviated from its usual procedures in deciding to close West Drive.").

63. 567 F.3d 976 (8th Cir. 2009). The court affirmed the lower court's decision to disregard damning extra-official evidence of discriminatory intent. See Gray v. City of Valley Park, No. 4:07CV00881 ERW, 2008 U.S. Dist. LEXIS 7238, at *83-84 (E.D. Mo. Jan. 31, 2008).

64. Gray, 567 F.3d at 979-80 ("Generally, ordinance 1722 prohibits all business entities in Valley Park from knowingly employing unauthorized aliens.").

65. Id.; see Gray, 2008 U.S. Dist. LEXIS 7238, at *2 (discussing the "landlord provision" penalizing landlords from renting to undocumented immigrants); Martos, supra note 8 , at 2118.

66. See Kristen Hinman, Valley Park to Mexican Immigrants: "Adios, Ilegals!," RIVERFRONT TTMES (Feb. 28, 2007), http://www.riverfronttimes.com/stlouis/news/valleypark-to-mexican-immigrants-adios-illegals/content?mode=print\&oid=2483315 (emphasis added) (noting that the mayor admitted his lawyers advised); see also Lozano v. City of Hazleton, 496 F. Supp. 2d 477, 540-41 (M.D. Pa. 2007).

67. Gray, 2008 U.S. Dist. LEXIS 7238, at *81-84 ("In support of [their] assertion, Plaintiffs point to evidence of comments made by the Mayor, and subsequently reported in a local newspaper article, as well as materials circulated to the Board of Alderman prior to the passage of the Ordinance .... However, [the] lack of discussion [at the Aldermen meeting] forces the Court to look more directly at the terms of the Ordinance, and the tes- 


\section{Discriminatory Intent Analysis and Religious Discrimination}

Although Davis and its progeny considered Fourteenth Amendment Equal Protection Clause challenges to racial classifications, courts apply a similar analytical framework to First Amendment Establishment Clause and Free Exercise Clause challenges asserting impermissible religious discrimination. The substantive standards for determining whether a First Amendment violation has occurred differs in some respects from a Fourteenth Amendment equal protection challenge, but the evidentiary framework articulated in Arlington Heights for assessing proof of a violation is largely the same. ${ }^{68}$ This approach to religious discrimination analysis makes sense, given the significant overlap between the non-discrimination goals of the Equal Protection Clause, the Establishment Clause, and the Free Exercise Clause. ${ }^{69}$

As with Fourteenth Amendment equal protection claims, First Amendment discrimination claims require proof of discriminatory purpose, not just discriminatory impact. For example, in Employment Division v. Smith, two members of a Native American religious sect whose rituals involved the use of peyote argued that state laws criminalizing peyote violated their First Amendment right to the free exercise of religion. ${ }^{70}$ The Supreme Court rejected their claim on the ground that the peyote laws at issue had not been passed for the purpose of impeding anyone's religious activity. ${ }^{71}$ While the law had that effect as applied to the challengers, the Court explained that the law would only have been unconsti-

timony of the Aldermen in their depositions. The Ordinance itself provides the reason for its passage, and each statement by the Aldermen support this purpose.").

68. See Steven G. Calabresi \& Abe Salander, Religion and the Equal Protection Clause: Why the Constitution Requires School Vouchers, 65 FLA. L. REV. 909, 1001-02 (2013) (discussing the changing nature of Free Exercise Clause and Establishment Clause cases in relation to modern equal protection jurisprudence).

69. See Bd. of Educ. v. Grumet, 512 U.S. 687, 728 (1994) (Kennedy, J., concurring) (emphasizing the centrality of the constitutional prohibition against religious discrimination: "Just as the government may not segregate people on account of their race, so too it may not segregate on the basis of religion").

70. 494 U.S. 872, 874 (1990) ("This case requires us to decide whether the Free Exercise Clause of the First Amendment permits the State of Oregon to include religiously inspired peyote use within the reach of its general criminal prohibition on use of that drug, and thus permits the State to deny unemployment benefits to persons dismissed from their jobs because of such religiously inspired use.").

71. Id. at 882-85 (finding that the law was not aimed specifically at a religious group but applied to everyone in order to promote public safety and maintain the integrity of the financial compensation fund). 
tutional if the state, in passing the law, had been motivated by the purpose of interfering with religious practice. ${ }^{72}$

A second area of jurisprudence where the Court has made use of subjective evidence of improper motive is the Establishment Clause of the First Amendment. ${ }^{73}$ Unlike in the Free Exercise Clause setting mentioned above, the Court has in several Establishment Clause rulings explicitly required that the government's motive be either secular or, at the very least, not a desire to favor some sects over others. ${ }^{74}$ It is perhaps this subtle burden shifting in Establishment Clause cases that explains why courts have appeared more willing to consider a wider range of "unofficial" evidence in the religious discrimination context.

For example, in Wallace $v$. Jaffree, the Court struck down an Alabama law mandating a moment of silence at the beginning of public school classes because the Court concluded, based in significant measure on historical evidence and legislative history, that the law was a backdoor attempt to reintroduce prayer in schools. ${ }^{75}$ In Jaffree, the Court conceded that a statute authorizing a moment of silence in public schools was facially neutral because it neither mentioned religion nor mandated students to do anything in particular during the moment of silence. ${ }^{76}$ But the Court also looked beyond the text of the statute to the legislative history, where the "sole purpose reflected in the official history [was] 'to return voluntary prayer to our public schools."'77 The

72. Id. at 877-79 (holding that such a "neutral law of general applicability" was constitutional, in contrast to "ban[ning] the casting of 'statutes that are to be used for worship purposes"').

73. See Grumet, 512 U.S. at 728 (Kennedy, J., concurring) ("Just as the government may not segregate people on account of their race, so too it may not segregate on the basis of religion."); Church of the Lukumi Babalu Aye, Inc. v. City of Hialeah, 508 U.S. 520, 532 (1993) ("In our Establishment Clause cases we have often stated the principle that the First Amendment forbids an official purpose to disapprove of a particular religion or of religion in general."); Larson v. Valente, 456 U.S. 228, 244-45 (1982) (holding that the "clearest command" of the Establishment Clause is that the government may not act with the discriminatory purpose to engage in "denominational preferen[tialism]").

74. See generally Santa Fe Indep. Sch. Dist. v. Doe, 530 U.S. 290 (2000) (finding that a policy permitting student-led, student-initiated prayer at high school football games violated the Establishment Clause because it was enacted for the purpose of granting preferentialism to religion); Lemon v. Kurtzman, 403 U.S. 602 (1971) (requiring the government, when faced with an Establishment Clause challenge, to affirmatively establish that the challenged action has a secular purpose).

75. 472 U.S. $38,41-45,60-61$ (1985)

76. Id. at 73 (O'Connor, J., concurring) ("By mandating a moment of silence, a State does not necessarily endorse any activity that might occur during the period.").

77. Id. at 77-78 ("Given this legislative history, it is not surprising that the State of 
Court also found dispositive candid testimony from Senator Donald Holmes, the sponsor of the first statute, who confirmed that he had "no other purpose in mind" than "to return voluntary prayer' to the public schools." 78

While the Court "peeked behind the curtain" of the Alabama statute in Jaffree, it nevertheless restricted itself to official legislative history and testimony. The Eleventh Circuit went further in Glassroth v. Moore, considering pre-election, "unofficial" campaign statements as relevant evidence in finding that the chief justice of the Alabama Supreme Court violated the Establishment Clause when he directed the installment of a Ten Commandments monument in the state supreme court's rotunda. ${ }^{79}$ The Court considered pre-election campaign statements by Chief Justice Moore and literature released by Moore's campaign that he was the "Ten Commandments Judge," as well as his statement during the unveiling that "in order to establish justice, we must invoke 'the favor and guidance of Almighty God." 80

Two years later, the Court invalidated a similar Ten Commandments display erected in the Kentucky statehouse, but harshly criticized the practice of considering any evidence beyond "the traditional external signs that show up in the 'text, legislative history, and implementation of the statute,' or comparable official act." 81 To do otherwise would risk leading to an unprincipled "judicial psychoanalysis of a drafter's heart of hearts." 82 At least in the establishment of religion context, the Court explained that an "objective observer" should only determine a government's purpose by examining "openly available data supported [by] a commonsense conclusion that a religious objective permeated the

Alabama conceded in the courts below that the purpose of the statute was to make prayer part of daily classroom activity, and that both the District Court and the Court of Appeals concluded that the law's purpose was to encourage religious activity.").

78. Id. at 56-57 (majority opinion).

79. 335 F.3d 1282, 1285, 1297 (11th Cir. 2003).

80. Id. at $1285-86$. While the Court's consideration of such statements did indeed reach beyond the four corners of the official government action, the Department of Justice argued in its brief before the Fourth Circuit in International Refugee that "Glassroth did not involve a facially neutral policy, but an explicitly religious display-a massive Ten Commandments monument-erected in the state supreme court's rotunda at the direction of the chief justice." Brief for Appellants at 52, Int'l Refugee Assistance Project v. Trump, 857 F.3d 554 (4th Cir. 2017) (No. 17-1351).

81. McCreary Cty. v. ACLU of Ky., 545 U.S. 844, 862 (2005) (quoting Santa Fe Indep. Sch. Dist. v. Doe, 530 U.S. 290, 308 (2000)).

82. Id. 
government's action." 33 "If someone in the government hides religious motive so well that" it does not appear in "the text, legislative history, and implementation of the statute," then he has not violated the Constitution because the government has not made "a divisive announcement that in itself amounts to taking religious sides." 84

This $M c$ Creary evidentiary approach adheres in part to the $A r$ lington Heights six-factor test in that it allows courts to look beyond the four corners of the government enactment. ${ }^{85}$ However, the McCreary approach artificially forecloses judicial analysis of evidence outside the official legislative history, which the Arlington Heights Court found vital to the analysis, such as the discriminatory effect of the action, the historical background, and any departures from normal substantive standards. ${ }^{86}$ As discussed below, however, even with this limitation, the McCreary analysis is being challenged by judges and commentators who want to foreclose any motive analysis beyond the four corners of the government action.

\section{Continued Resistance to Motive Analysis}

Liberal resistance to discriminatory motive analysis generally seeks a return to disparate impact analysis, and thus a return to objective empirical reasoning and more successful civil rights litigation. But it is vocal conservative resistance to motive analysis in the context of the executive order litigation that has garnered significantly more attention in recent years. While some judges, including Ninth Circuit Judge Jay Bybee, have suggested that review of the constitutionality of the executive order should be limited to the four corners of the document and that judges should refrain from peeking "behind the curtain" of the order, ${ }^{87}$ this four corners view is belied by the decades of settled case law confirming that motive matters in assessing First Amendment religious

83. Id. at 863 .

84. Id.

85. See id. at 862; Village of Arlington Heights v. Metro. Hous. Dev. Corp., 429 U.S. $252,266-68$ (1979).

86. See McCreary, 545 U.S. at 862; but see Arlington Heights, 429 U.S. at 266-67.

87. Washington v. Trump, 858 F.3d 1168, 1183 (9th Cir. 2017) (Bybee, J., dissenting) (" $[\mathrm{f}$ we have questions about the basis for the President's ultimate findings," courts cannot "peek behind the curtain," even if it is to determine whether the executive order is a "Muslim ban' or something else."). 
discrimination and Fourteenth Amendment equal protection challenges. ${ }^{88}$

Perhaps the most troubling and misguided expression of this conservative sentiment was articulated by commentator Jeffrey Toobin, who questioned the Ninth Circuit's consideration of Trump's campaign statements, arguing that "[t]heir reliance on such statements leads to a peculiar and unsettling possibility: that an identical order would be upheld if Barack Obama had issued it, but that this one was invalidated because Trump was the author." 89

Toobin questioned whether it could really be the case that Trump's executive orders are unconstitutional while the exact same orders would be valid if they had been issued by President Obama, who did not make any anti-Muslim statements..$^{90}$ If Obama had issued orders like these and was motivated by antiMuslim prejudice, then his orders would have been just as unconstitutional as Trump's orders. "Indeed, [they would] have been unconstitutional whether or not Obama had announced his prejudice publicly; what makes Trump's orders unconstitutional is his motivation, not his statements, and his statements are significant because they are evidence of his unconstitutional motive." 91 So, it is not that the same action would have been constitutional if taken by Obama but unconstitutional if taken by Trump; it is that the same action can be constitutional if taken for permissible purposes but unconstitutional if the motive is discriminatory, and Trump is a president who has declared his discriminatory motivation.

88. See McCreary, 545 U.S. at 866 \& n.14 ("[T] he same government action may be constitutional if taken in the first instance and unconstitutional if it has a sectarian heritage."); Books v. Elkhart Cty., 401 F.3d 857, 869 (7th Cir. 2005) (sustaining the Ten Commandments display as "secular ... in its purpose and effect"); ACLU of Tenn. v. Rutherford Cty., 209 F. Supp. 2d 799, 808-09 (M.D. Tenn. 2002) (holding the same Ten Commandments display to be unconstitutional based on the intent of the county commission decision to erect it, not the display itself); ACLU of Ky. v. Mercer Cty., 219 F. Supp. 2d 777, 787-89 (E.D. Ky. 2002) (rejecting an Establishment Clause challenge to an identical Ten Commandments display and distinguishing itself on the ground that the County's purpose had not been "tainted with any prior history").

89. Toobin, supra note 13.

90. Id. (suggesting this possibility confirms that campaign statements are inappropriate "evidence for judges to rely on in deciding the validity of Presidential orders").

91. Richard Primus, Motive Matters in Assessing the Travel Ban, TAKE CARE (Mar. 20, 2017), https://takecareblog.com/blog/motive-matters-in-assessing-the-travel-ban. 
Toobin's argument willfully ignores the essence of discriminatory intent analysis. It has been the law of the land for more than four decades that a facially neutral government action may nevertheless be unconstitutionally discriminatory if the intent behind the action was driven by prejudice. ${ }^{92}$ The intent of a facially neutral statute must, by definition, be derived outside the four corners of the statute itself. To say that "[t]he Muslim ban is either constitutional or it's not" ignores what makes such statutes unconstitutional-the extra-statutory intent. ${ }^{93}$

Assessing the purpose behind an action is a common task for courts. ${ }^{94}$ "One consequence of taking account of the purpose underlying past actions is that the same government action may be constitutional if taken in the first instance and unconstitutional if it has a sectarian heritage. This presents no incongruity, however, because purpose matters." 95 Across all of these contexts, government action that would be constitutional if undertaken for permissible motives is unconstitutional if undertaken for forbidden motives. ${ }^{96}$ Assessing the government's purposes in acting is, accordingly, a routine and indispensable part of constitutional adjudication. And there can be no serious doubt that Trump's statements about banning Muslims tell us something about why these executive orders were issued. ${ }^{97}$

92. See Washington v. Davis, 426 U.S. 229, 241 (1976) ("A statute, otherwise neutral on its face, must not be applied so as invidiously to discriminate on the basis of race" and must not have been enacted for a discriminatory purpose.).

93. Toobin, supra note 13 , at 240 . See Davis, 426 U.S. at 241 ("[T] he invidious quality of a law claimed to be racially discriminatory must ultimately be traced to a racially discriminatory purpose.").

94. McCreary Cty. v. ACLU of Ky., 545 U.S. 844, 861 (2005).

95. Id. at 866 n.14.

96. See, e.g., ACLU of Ky. v. Mercer Cty., 219 F. Supp. 2d 777, 787-89 (E.D. Ky. 2002) (illustrating that a government display found unconstitutional in one context was found constitutional in another context because the purpose in the latter case had not been "tainted with any prior history").

97. See Alana Abramson, What Trump Has Said About a Muslim Registry, ABC NEWS (Nov, 18, 2016), http://abcnews.go.com/Politics/trump-muslim-registry/story?id=43639946 (documenting then-candidate Trump's numerous statements about a possible Muslim tracking system, including the following answer to the question "Ts there going to be a database that tracks the Muslims here in this country?" as "Oh I would certainly implement that. Absolutely”); Amy B. Wang, Trump Asked for a 'Muslim Ban,' Giuliani Says-and Ordered a Commission to Do It Legally,' WASH. PosT (Jan. 29, 2017), https://www.washi ngtonpost.com/news/the-fix/wp/2017/01/29/trump-asked-for-a-muslim-ban-giuliani-says-an d-ordered-a-commission-to-do-it-legally/?utmterm=.db4Fefa574c6 ("So when [Trump] first announced it, he said, 'Muslim ban.' He called me up. He said, 'Put a commission together. Show me the right way to do it legally." (alteration in original)); see also Faiza Patel, Yates Letter Points to Evidence Showing Executive Order Unconstitutional, JUST SECURITY (Jan. 
But whether an action is constitutional often depends on the reason why it was taken-the real reason, not the prettified reason that the government pretextually offers in court to defend its action from constitutional attack....

... If the President's statements show, either alone or in combination with other evidence, that the executive orders were motivated by anti-Muslim prejudice, then the government cannot save the orders by insisting officially that the motives behind them are benign. If the Administration doesn't want its orders to be struck down, it shouldn't act on the basis of discriminatory motives. ${ }^{98}$

In short, where clear evidence of discriminatory motive exists, it cannot be ignored.

\section{E. Conclusion}

Despite the facially broad evidentiary record theoretically available to courts as articulated by the Arlington Heights sixfactor test, four decades of post-Arlington Heights jurisprudence highlight a much more restrained approach taken by courts, one which limits judicial inquiry of intent to official governmental records such as official city council minutes or drafts of legislative materials. For a variety of reasons, courts have been reluctant to tread beyond these tangible, officially sanctioned documents to look for discriminatory animus, even where a consistent and indisputable record of discriminatory statements from government officials exists.

Indeed, courts consistently reject evidence that could satisfy any one of the Arlington Heights factors, requiring instead explicit evidence of a perpetrator's subjective intent to discriminate. The factors are broad and arguably encompass a wide range of potentially probative evidence. In particular, factors (2) and (3) appear to contemplate consideration of extra-official political statements, including statements made by elected officials and campaign statements by political candidates.

31, 2017), https://www.justsecurity.org/37053/yates-letter-points-evidence-showing-execu tive-order-unconstitutional/ ("According to Giuliani, he put together a 'commission,' which came up with the idea of focusing on danger rather than religion; the ban was based 'on places where there are [sic] substantial evidence that people are sending terrorists into our country.' Of course, as many have pointed out, the countries affected by the ban have hardly been a source of terrorist attacks in the United States."); id. (noting that the son of then-National Security Advisor Michael Flynn praised the executive order the day after it was signed in a tweet stating "\#MuslimBan").

98. Primus, supra note 91. 
This "process of identifying discriminatory intent involves an oversimplified and narrow understanding of evidence."99 Why have courts willingly considered the historical background of a decision or the specific sequence of events preceding the decision when they appear in the official legislative or administrative record but resisted the urge to consider historical background or specific sequence of events when such evidence appears in media interviews, electoral debates, or campaign stump speeches? As the court in International Refugee correctly observed, nothing prohibits courts from considering such extra-official evidence under $\mathrm{Ar}$ lington Heights. ${ }^{100}$ The following section highlights the five primary arguments advanced against consideration of campaign statements and explains why these arguments cannot survive logical or precedential scrutiny.

\section{They'Ll "SAY ANYTHING To GET ELECTED"101: THE PECULIAR CASE OF CAMPAIGN RHETORIC}

As illustrated above, courts remain reluctant to invoke the second and third Arlington Heights factors to consider evidence of discriminatory intent beyond the four corners of an official governmental record, even though no doctrinal restriction prevents them from doing so. This section explores one such category of extra-official evidence campaign statements-and examines the primary arguments advanced by judges and scholars as to why campaign statements should be inadmissible per se in the discriminatory intent analysis. Broadly speaking, these arguments address two types of issues: (1) the evidentiary concern that campaign speech is insufficiently reliable, and (2) the normative

99. Martos, supra note 8 , at 2102.

100. Int'l Refugee Assistance Project v. Trump, 857 F.3d 554, 598-99 ("But we decline to impose a bright-line rule against considering campaign statements, because as with any evidence, we must make an individualized determination as to a statement's relevancy and probative value in light of all the circumstances.").

101. Jim Swift, Cooper to Hillary: "Will You Say Anything to Get Elected?, WKLY. STANDARD (Oct. 13, 2015), http:/www.weeklystandard.com/print/cooper-to-hillary-will-you -say-anything-to-get-elected/article/1045235 (recounting debate moderator Anderson Cooper's summary of Hillary Clinton's politically expedient policy changes from campaign to campaign); Raul A. Reyes, Trump Will Say Anything to Get Elected, CNN (June 29, 2016), http://www.cnn.com/2016/06/28/opinions/trump-shifting-views-reyes/index.html ("Get out your Etch A Sketch-Donald Trump might be able to redraw another one of his positions."). 
judgment that freedom of political speech and freedom of governments to enact laws are equally important ideals that are best protected when left separable and distinct from one another.

\section{A. Evidentiary Concerns: Lies, Slippery Slopes, and Straitjackets}

Critics of "peeking behind the curtain" of official records to discern government intent via campaign statements raise several distinct but related concerns that can fairly be characterized as evidentiary in nature. These concerns focus on the relative unreliability of campaign statements to divine true motive. Unlike analyzing official government records, critics claim that attempting to uncover subjective motivation by sifting through mountains of campaign statements amounts to little more than untethered "judicial psychoanalysis of a drafter's heart of hearts." ${ }^{102}$ In other words, the evidence is inherently of little use and may even prove prejudicial given its inherent unreliability. ${ }^{103}$

These reliability concerns underlie three basic arguments against considering campaign speech. The first argument asserts that campaign statements are inherently unreliable because they are often informal and improvised, and because the true intent of the speaker is to secure election by any means necessary. ${ }^{104}$ The second argument claims that a dangerous evidentiary slippery slope lurks just beneath the consideration of campaign statements. ${ }^{105}$ If off-the-cuff statements of private citizen candidates

102. McCreary Cty. v. ACLU of Ky., 545 U.S. 844, 862 (2005) ("But scrutinizing purpose does make practical sense... where an understanding of official objective emerges from readily discoverable fact, without any judicial psychoanalysis of a drafter's heart of hearts. The eyes that look to purpose belong to an 'objective observer,' one who takes account of the traditional external signs that show up in the 'text, legislative history, and implementation of the statute' or comparable official act." (citations omitted)).

103. See, e.g., Washington v. Trump, 858 F.3d 1168, 1173 (9th Cir. 2017) (Kozinski, J., dissenting) (decrying reliance on campaign statements as "folly": "Candidates say many things on the campaign trail; they are often contradictory or inflammatory"). Int' $l$ Refugee, 857 F.3d at 649-50 (Niemeyer, J., dissenting) ("Because of their nature, campaign statements are unbounded resources by which to find intent of various kinds. They are often short-hand for larger ideas; they are explained, modified, retracted, and amplified as they are repeated and as new circumstances and arguments arise.").

104. Eugene Kontorovich, The 9th Circuit's Dangerous and Unprecedented Use of Campaign Statements to Block Presidential Policy, WASH. PosT (Feb. 9, 2017), https:// www.washingtonpost.com/news/volokh-conspiracy/wp/2017/02/09/the-9th-circuits-dangero us-and-unprecedented-use-of-campaign-statements-to-block-presidential-policy/ (asserting that campaign statements have one explicit purpose-to secure election).

105. See Int'l Refugee, 857 F.3d at 650 (Niemeyer, J., dissenting) ("If a court, dredging through the myriad remarks of a campaign, fails to find material to produce the desired 
are fair game, then what prevents courts from considering statements made before the campaign? ${ }^{106}$ The third argument questions whether a campaign statement, once ruled relevant to the analysis, can ever lose its relevance. ${ }^{107}$ In other words, can a politician who once uttered a discriminatory statement ever outrun the effects of that statement for purposes of governing, or will every official action taken from that point forward be tainted with the whiff of unconstitutional motive? ${ }^{108}$

Each of these arguments articulate a concern on the pendulum of evidentiary weight rather than an absolutist admissibility concern-that is, how relevant the speech is and not whether it is relevant at all. Yet those advancing these arguments rely on them to justify an absolutist, per se ban on the admissibility of campaign rhetoric. This disconnect between holding and reasoning cannot be squared as a matter of law or logic. As with all traditional evidentiary analysis, the dividing line between when evidence of discriminatory intent should be admitted and when such evidence is entitled to considerable weight by the fact finder is often difficult to discern. But while certain types of campaign speech are certainly of less probative value than others, the following discussion highlights why this simple fact of evidentiary weight does not and should not justify a bright-line admissibility rule regarding campaign speech.

\section{The De Minimis Probative Value of Campaign Rhetoric: The "They're All Liars" Argument}

As the title of this article and the introductory quote by Judge Kozinski suggest, the first and most prominent argument ad-

outcome, what stops it from probing deeper to find statements from a previous campaign, or from a previous business conference, or from college?").

106. See Washington v. Trump, 858 F.3d at 1173 (Kozinski, J., dissenting) ("Eager research assistants can discover much in the archives, and those findings will be dumped on us with no sense of how to weigh them. ... What is the appropriate place of an overzealous senior thesis or a poorly selected yearbook quote?").

107. See Int'l Refugee, 857 F.3d at 650-51 (Niemeyer, J., dissenting) ("[T] he unbounded nature of the majority's new rule will leave the President and his Administration in a clearly untenable position for future action. It is undeniable that President Trump will need to engage in foreign policy regarding majority-Muslim nations, including those designated by the Order. And yet the majority now suggests that at least some of those future actions might also be subject to the same challenges upheld today.").

108. Washington v. Trump, 858 F.3d at 1174 (Kozinski, J., dissenting) ("Even if a politician's past statements were utterly clear and consistent, using them to yield a specific constitutional violation would suggest an absurd result-namely, that the policies of an elected official can be forever held hostage by the unguarded declarations of a candidate."). 
vanced by judges and commentators against weighing campaign statements as evidence of motive is that such statements are unreliable. This argument takes one of two forms. Some, such as legal analyst Jeffrey Toobin and Professor Katherine Shaw, claim that campaign statements lack the formality and measured gravitas of official governmental records to be considered reliable. ${ }^{109}$ Others, such as Judge Kozinski and Professor Eugene Kontorovich, claim that such statements are poor indicators of a politician's true policy motives because they are designed primarily to entice voters to vote for them. ${ }^{110}$ Put another way, politicians say and do anything to get elected, so we should acknowledge that fact and move on.

According to Toobin, courts willing to evaluate informal campaign statements are essentially "playing gotcha" with an elected official by "accusing him of saying one thing in public while his Administration was saying something else in court":

Candidates (and, to a lesser extent, Presidents) talk publicly all the time. They say things off the cuff, improvising in the moment and sometimes making foolish statements or outright mistakes.... In contrast, a formal action by the President's Administration, in the form of an executive order, is by definition a statement of concrete . policy, issued in contemplation of a legal challenge. These actions should stand or fall on their own merits. ${ }^{111}$

This view ignores the entire second step of the Arlington Heights analysis-namely, that where direct evidence of discrimination is lacking, courts should analyze the "historical context," the "specific sequence of events leading up to the challenged decision," and any departures from procedural or substantive norms. ${ }^{112}$ By claiming that only a formal action, such as an execu-

109. Katherine Shaw, Beyond the Bully Pulpit: Presidential Speech in the Courts, 96 TEX. L. REV. (forthcoming 2017) (manuscript at 7), https://papers.ssrn.com/sol3/papers. cfm?abstract_id=2981475 (" $\mathrm{T}] \mathrm{t}$ is a category error for a court to give legal effect to presidential statements whose goals are political storytelling, civic interpretation, persuasion and mobilization-not the articulation of considered legal positions."); Toobin, supra note 13 ("Candidates... say things off the cuff, improvising in the moment and sometimes making foolish statements or outright mistakes.").

110. Kontorovich, supra note 104; Washington v. Trump, 858 F.3d at 1173 (Kozinski, J., dissenting).

111. Toobin, supra note 13.

112. Village of Arlington Heights v. Metro. Hous. Dev. Corp., 429 U.S. 252, 253, 260, 267 (1977); see Heidi Kitrosser, Is Speech from the Campaign Trail Relevant to Religious Discrimination Claims?, ACS BLOG (Mar. 20, 2017), https://www.acslaw.org/acsblog/sho uld-elected-officials-be-held-accountable-in-court-for-campaign-speech ("[I]t is well established that courts may-indeed, often must-look beyond the face of a law to determine 
tive order or legislative enactment, contains the requisite formality for consideration, Toobin, Judge Bybee, and others seek to cut the Arlington Heights discriminatory intent analysis off at the knees, with the effect of invalidating only those actions with express discriminatory motives contained within the four corners of the document. Such a restrictive view not only provides an open invitation for prejudiced lawmakers to dress up discriminatory laws as facially neutral, but also finds no support in post-Davis precedent. ${ }^{113}$

This formality argument also fails as a matter of logic, at least with respect to unambiguous and consistent campaign speech. These types of campaign statements "often provide a clear window to the candidate's true intent." 114 For example, in Decorte $v$. Jordan, the Fifth Circuit affirmed a jury finding that a recently elected Louisiana district attorney had unconstitutionally acted with a racially discriminatory purpose when he replaced more than fifty white employees almost exclusively with African Americans. ${ }^{115}$ The district attorney formally advanced race-neutral reasons for these decisions, but the court sensibly took into consideration his repeated public pledges during his campaign to make his staff's "racial composition" more reflective of his parish's population, which was overwhelmingly African American. ${ }^{116}$ Cen-

whether it is motivated partly by a discriminatory purpose.").

113. Toobin, supra note 13. Indeed, Toobin's invitation for executives to draft orders "in contemplation of a legal challenge" is practically begging for a pretext. Id.; see also Segal, supra note 4 ("So which is more probative of the President's true intent: his formal campaign promise, or briefs from lawyers given the unenviable task of laundering the President's intentions? The answer is obvious.").

114. Segal, supra note 4; see Kitrosser, supra note 112 ("To be sure, judicial inquiries into alleged discriminatory purposes are highly context-sensitive. . . [But] a long history of public statements promising to take a particular action against a given group may well convince a court that the promised action, once taken, does purposefully discriminate against that group.").

115. 497 F.3d 433, 438-40 (5th Cir. 2007) ("The evidence showed that, within the first 72 days Jordan was in office, the racial composition of the DA's non-attorney staff changed from 77 whites and 56 blacks to 27 whites and 130 blacks. . . Of the 56 non-attorney employees Jordan terminated, 53 were white, one was Hispanic, and two were black. Plaintiffs' statistician testified that, according to his analyses: the probability that 53 out of 56 terminated employees would be white if the terminations were race-neutral was less than one in 10,000; and the probability of the racial composition changing as it did in Jordan's first 72 days, if the decisions had been made randomly, was less than one in one million.").

116. Id. at 436 (The court observed that, shortly after his election, Jordan's appointed transition team "compiled a report of its recommendations for Jordan in his new position. The report included a cultural-diversity report recommending, within 100 days of his taking office, Jordan's hiring a staff reflective of New Orleans' racial composition. This recommendation was based on a Jordan campaign promise."). 
tral to the court's decision was the fact that there existed a direct connection between his actions and this discriminatory "campaign promise." 117

Trump's executive orders' connection to a discriminatory campaign promise is even clearer. Then-candidate Trump's campaign promises of a "Muslim ban" were far more formal, orchestrated, and deliberative than the district attorney's promises in Decorte $v$. Jordan. Contrary to Toobin's characterization of Trump's pledges as "improvisations" and "utterances," then-candidate Trump's "Muslim ban" proposal was formally rolled out as a policy position on his campaign's website, ${ }^{118}$ in campaign literature, ${ }^{119}$ in talking points with his surrogates, ${ }^{120}$ and in a major policy speech delivered via teleprompter on December 7, 2015, when he called "for a total and complete shutdown of Muslims entering the United States until our country's representatives can figure out what the hell is going on."121 It stretches the imagination to conjure a more formal or explicitly discriminatory campaign promise.

In addition to attacking campaign speech as inherently too "informal," Judge Kozinski and others assert that all campaign

117. Id. at 441.

118. See Jose A. DelReal, Trump Campaign Staff Redirects, Then Restores, Mention of Muslim Ban from Website, WASH. POST (Nov. 10, 2016), https:/www.washingtonpost.com/ news/post-politics/wp/2016/11/10/trump-campaign-staff-deletes-mention-of-muslim-ban-fr om-website/?utm term=.8f5be6fe7755 ("President-elect Donald Trump's campaign staff temporarily redirected the webpage detailing his controversial proposal to temporarily ban Muslim immigration into the United States, one of the most divisive and controversial policy ideas of his campaign, but swiftly sought to restore it after reporter inquiries Thursday. The proposal is detailed on a page titled, 'Donald J. Trump statement on Preventing Muslim Immigration."').

119. See Jill Colvin \& Steve Peoples, Trump's First TV Ad Spotlights Muslim Ban, PBS (Jan. 4, 2016, 7:30 PM), http://www.pbs.org/newshour/rundown/trump-debuts-first-tv-adfor-early-voting-states/ "With the opening 2016 primary contest four weeks away, Trump is spotlighting his plan to ban Muslims from entering the United States.").

120. Allegra Kirkland, Trump's Ever-Morphing Muslim Ban Is Getting More and More Confusing, TALKING POINTS MEMO (June 28, 2016, 3:18 PM), http://talkingpointsmemo. com/news/trumps-morphing-muslim-ban.

121. Jenna Johnson, Trump Calls for 'Total and Complete Shutdown of Muslims Entering the United States, WASH. POST (Dec. 7, 2015), https://www.washingtonpost.com/news/ post-politics/wp/2015/12/07/donald-trump-calls-for-total-and-complete-shutdown-of-musli mims-entering-the-united-states/?utm_term=.f1cedbfda5b06 (The call was contained in a formal "statement released by the campaign," which Trump read verbatim at a rally after "[t]he crowd enthusiastically agreed that he should. 'Donald J. Trump is calling for a total and complete shutdown of Muslims entering the United States until our country's representatives can figure out what the hell is going on,' he said, adding the word 'hell' for emphasis this time."). 
speech is inherently unreliable because all politicians invariably lie to get elected, and thus no campaign rhetoric can reliably indicate any intent besides the intent to win the election. ${ }^{122}$ Given this self-interested motive, critics argue that courts should ignore campaign statements because "campaign promises are often insincere, designed to appeal to voters. Indeed, they are explicitly instrumental, and the goal is not policy outputs, but election."123 In other words, politicians in campaign mode are expected to lie; therefore, their statements cannot and should not be taken at face value.

The stereotypical political candidate described here is the one who will say anything to get elected, even if that means saying one thing at 10:00 a.m., another thing at noon, and a third thing at 6:00 p.m. In making his point about the "poor shlub[" just trying to get elected, Judge Kozinski repeated the apocryphal tale of President Franklin Roosevelt giving one policy speech in the countryside and the exact opposite policy speech in the city solely for the purpose of securing election. ${ }^{124}$ Indeed, it is true there is no shortage of candidates for office contradicting themselves over the course of a campaign, just as there is no shortage of "dark purpose" that can be found in a candidate's campaign rhetoric. ${ }^{125}$

Kozinski's argument may rest on the "typical" case of a duplicitous politician, but the court can readily take into account and discount where appropriate the evidentiary weight of contradictory statements of intent. ${ }^{126}$ As with Toobin's formality argument, Kozinski's veracity argument articulates a concern that is a mat-

122. Washington v. Trump, 858 F.3d 1168, 1173 (9th Cir. 2017) (Kozinski, J., dissenting) ("No shortage of dark purpose can be found by sifting through the daily promises of a drowning candidate, when in truth the poor shlub's only intention is to get elected."); Int'l Refugee Assistance Project v. Trump, 857 F.3d 554, 650 (4th Cir. 2017) (Niemeyer, J., dissenting) ("Is there not the possibility that a candidate might have different intentions than a President in office?").

123. Kontorovich, supra note 104.

124. Washington v. Trump, 858 F.3d at 1173 \& n.3 (Kozinski, J., dissenting).

125. Id. at 1173; see Mark Murray, The Art of the Flip-Flop: Breaking Down the 2016 Reversals, MSNBC (July 22, 2015), https://www.nbcnews.com/meet-the-press/art-flip-flopbreaking-down-2016-reversals-n396546 (summarizing the contradictory positions taken by Republican presidential candidates during the 2016 primaries).

126. See Int'l Refugee, 857 F.3d at 598-99 (declining to impose a bright-line rule rejecting consideration of campaign statements because "we must make an individualized determination as to a statement's relevancy and probative value in light of all the circumstances," including the consistency or contradictory nature of the statements); Kitrosser, supra note 112 ("[S] uch inconsistency itself is a factor that courts can and should consider in sifting through all of the relevant evidence."). 
ter of degrees rather than absolutes, of evidentiary weight rather than admissibility. In the adversarial litigation context, the two sides will doubtlessly marshal evidence indicative of inconsistent, ambiguous, or contradictory campaign pledges rendering such statements of limited probative value in divining intent. Indeed, we readily expect a candidate to "play to the base" and offer up "red meat" campaign pledges to diehard supporters of her chosen political party, only to soften her stance or even abandon those more extreme promises as she strategically "plays to the middle" in the general election. In this "typical" case, courts are more than equipped to give such contradictory statements the appropriate weight.

In addition to sidestepping the routine nature of weighing contradictory evidence during litigation, what Kozinski's bright-line rule ignores is the atypical case of a candidate who speaks his mind and who candidly and consistently makes his discriminatory motives known. ${ }^{127}$ For example, then-candidate Trump first formally announced his call for a "Muslim ban" on December 7, 2015, before a single Republican caucus or primary had been held. ${ }^{128} \mathrm{He}$ consistently reiterated his call for such a ban throughout the primary season and into the general election, pledging as late as Election Day itself to implement an "extreme vetting" travel ban premised on his original call to bar Muslims from entering the United States. ${ }^{129}$

Courts should not be hamstrung from making sensible rulings in such cases by a logically flawed admissibility rule. ${ }^{130}$ Such a

127. See Int'l Refugee, 857 F.3d at 600 ("Indeed, this case is unique not because we are considering campaign statements, but because we have such directly relevant and probative statements of government purpose at all.").

128. See Abramson, supra note 97; Johnson, supra note 121; Patel, supra note 97; Wang, supra note 97; see also David Jackson, Donald Trump's Call for Banning Muslims from Entering U.S. Draws Condemnation, USA TODAY (Dec. 7, 2015), https://www.usatod ay.com/story/news/politics/elections/2015/12/07/donald-trump-muslims-united-states/769 $42932 /$.

129. See Johnson, supra note 121; Trump's Promises Before and After the Election, BBC NEws (Sept. 19, 2007), http://www.bbc.com/news/world-us- canada-37982000.

130. See Int'l Refugee, 857 F.3d at 600-01 ("[C]ourts regularly evaluate decisionmakers" statements that show their purpose for acting. ... We therefore see nothing 'intractable' about evaluating a statement's probative value based on the identity of the speaker and how specifically the statement relates to the challenged government action."); Kitrosser, supra note 112 ("The question, then, is whether there exists any good reason to exempt presidential campaign statements from the realm of evidence that courts can consider in cases alleging religious discrimination. The answer is that there is none. While a presidential candidate may make conflicting statements at different times and to different audiences, that is true of many other categories of written and oral communication."). 
rule not only contradicts the intent of the Arlington Heights sixfactor test, but also risks forcing courts to turn a blind eye to incontrovertible evidence of discriminatory intent. At that point, courts reviewing the constitutionality of a facially neutral zoning ordinance banning the presence of "illegal immigrants" would arbitrarily be forced to ignore a mayor's campaign statements that his pivotal role in passing the ordinance was necessary lest, "[y]ou g[e]t one guy and his wife that settle down here, have a couple kids, and before long you have Cousin Puerto Rico and Taco Whoever moving in." 131 Likewise, courts reviewing the constitutionality of a facially neutral executive order banning immigration from seven Middle Eastern countries with Muslim populations ranging from $71.4 \%$ to $99.7 \%{ }^{132}$ —stensibly to "prevent terrorism" despite the absence of historical evidence of nationals from these countries seeking to commit terror inside the United States-would arbitrarily be forced to ignore the statements of the executive entering the order emphasizing his desire to ban all Muslims from entering the United States. ${ }^{133}$

Judge Kozinski claims that considering Trump's campaign statements would require "[w]eighing... imponderables [and] precisely the kind of 'judicial psychoanalysis' that the Supreme Court has told us to avoid." 134 But when campaign statements are utterly clear, utterly consistent, and wrapped in the formality of a major policy speech and position statement on a campaign website, "[s]uch explicit statements of a religious purpose are 'readily discoverable fact[s]' that allow the Court to identify the purpose of this government action without resort to 'judicial psychoanaly-

131. See Lozano v. City of Hazleton, 496 F. Supp. 2d 477, 540-41 (M.D. Pa. 2007); see also Hinman, supra note 66 (emphasis added).

132. Muslim Populations by Country: How Big Will Each Muslim Population Be by 2030?, GUARDIAN (Jan. 28, 2011), https://www.theguardian.com/news/datablog/2011/jan/ 28/muslim-population-country-projection-2030 (summarizing data by Pew Forum on Religion \& Public Life).

133. See Rebecca Hamilton, Why Trump's Selection of the Seven Countries Is Not the Same as Obama's, JUST SECURITY (Jan. 31, 2017, 9:59 AM), https://www.justsecurity.org /37041/trumps-selection-countries-obamas/ ("[N]ot one Syrian, Iraqi, Sudanese, or any other national from a country of concern has killed anyone in a terrorist attack in the U.S. going back to at least 9/11."); James C. Hathaway, Executive (Dis)order and Refugees-The Trump Policy's Blindness to International Law, JUST SECURITY (Feb. 1, 2017, 8:05 AM), https://www.justsecurity.org/37113/executive-disorder-refugees-the-trump-policys-blind ness-inter national-law/ (observing that there is "no rational connection between refugees fleeing the seven listed countries and the threat of terrorism (or indeed any other threat) ....").

134. Washington v. Trump, 858 F.3d 1168, 1173 (9th Cir. 2017) (Kozinski, J., dissenting) (quoting McCreary Cty. v. ACLU of Ky., 545 U.S. 844, 862 (2005)). 
sis." 135 Judge Kozinski may be correct that there exists "no case anywhere" that "sweeps so widely in probing politicians for unconstitutional motives," but the absence of such a case does not explain why such a case should never exist. ${ }^{136}$ Indeed, no rule exists to limit consideration of such consistently discriminatory extrinsic evidence. ${ }^{137}$ Moreover, the notion that "[l]imiting the evidentiary universe to activities undertaken while crafting an official policy makes for a manageable, sensible inquiry"138 ignores just how insensible it would be to ignore the evidentiary universe predating those activities in the current climate. Indeed, as with many aspects of the Trump era, Trump's campaign statements appear so unprecedented in their explicitly discriminatory nature (at least for the twenty-first century) that probing them for unconstitutional motives seems not only necessary and legally justifiable, but obvious. ${ }^{139}$ Defendants argue that because they were made outside the formal governmental decisionmaking process or before President Trump became a government official, they are inadmissible. ${ }^{140}$

135. Int'l Refugee Assistance Project v. Trump, 241 F. Supp. 3d 539, 559 (D. Md. 2017) (quoting $M c$ Creary, 545 U.S. at 862); cf. Palmer v. Thompson, 403 U.S. 217, 224 (1971) (asserting that searching for governmental purpose outside the operative terms of governmental action and official pronouncements is fraught with practical "pitfalls" and "hazards" that would make courts' task "extremely difficult").

136. See Washington v. Trump, 858 F.3d at 1173 (Kozinski, J., dissenting). The closest analog may be the litigation involving another highly publicized controversial political figure-former Alabama Supreme Court Chief Justice Roy Moore. Moore directed the installment of a massive statute of the Ten Commandments at the Supreme Court, which the Eleventh Circuit found was impermissibly driven for a religious purpose as evidenced by Chief Justice Moore's statement at the dedication ceremony that "in order to establish justice, we must invoke "the favor and guidance of Almighty God." Glassroth v. Moore, 335 F.3d 1282, 1284, 1286 (11th Cir. 2003). See also id. at 1296 ("[N]o psychoanalysis or dissection is required here, where there is abundant evidence, including his own words, of the Chief Justice's purpose.").

137. Int'l Refugee, $241 \mathrm{~F}$. Supp. 3d at 560-61. ("Although McCreary . . states that a court considers 'the text, legislative history, and implementation' of an action and 'comparable' official acts, it did not purport to list the only materials appropriate for consideration. . . . Notably, in Green $v$. Haskell County Board of Commissioners], [the Tenth Circuit] considered quotes from county commissioners that appeared in news reports in finding that a Ten Commandments display violated the Establishment Clause. ... . Likewise, in Glassroth, [the Eleventh Circuit] found an Establishment Clause violation based on a record that included the state chief justice's campaign materials, including billboards and television commercials, proclaiming him to be the "Ten Commandments Judge.").

138. Washington v. Trump, 858 F.3d at 1173 (Kozinski, J., dissenting).

139. See Int'l Refugee Assistance Project v. Trump, 857 F.3d 554, 599-600 (4th Cir. 2017) (noting how remarkable it is that a clear evidentiary record of executive purpose exists from the President's own unambiguous words); Segal, supra note 4 ("Given the Trump Administration's many anti-Muslim statements, it's hard to imagine how the ban could be upheld by any court that gives serious weight to that evidence.").

140. Int'l Refugee, 857 F.3d at 598. 


\section{The Evidentiary Slippery Slope Argument}

The second concern raised against analyzing campaign speech can be fairly characterized as the "evidentiary slippery slope" argument. As Judge Kozinski rhetorically bemoaned, "[W]hy stop with the campaign? Personal histories, public and private, can become a scavenger hunt for statements that a clever lawyer can characterize as proof of a -phobia or an -ism." ${ }^{141}$ When no brightline limits are placed on permissible evidence of intent, "eager research assistants" will deluge the courts with mountains of past statements but will leave the court "with no sense of how to weigh them." 142

These concerns are legitimate, but they again speak more to evidentiary weight than admissibility. The fact that evidence may be of limited probative value does not, by itself, caution against its admissibility. Indeed, judges and juries are asked every day to weigh competing evidence of varying probative value, discount accordingly, and render decisions. ${ }^{143}$ While divining an actor's state of mind is difficult, whether it be scienter in a securities fraud action or discriminatory intent in an equal protection challenge, the mere existence of a difficult fact-finding mission does not mean that, as a matter of law, it should not be undertaken.

More to the point, judges are more than capable of discounting evidence as less probative given the context within which the statement was made, the time at which it was made relative to the challenged governmental action, and whether the statement preceded any suspicious or abnormal activity. ${ }^{144}$ In fact, the $A r$ -

141. Washington v. Trump, 858 F.3d at 1173 (Kozinski, J., dissenting).

142. Id.; see also Intl Refugee, 857 F.3d at 650 (Niemeyer, J., dissenting) ("[O]pening the door to the use of campaign statements to inform the text of later executive orders has no rational limit. If a court, dredging through the myriad remarks of a campaign, fails to find material to produce the desired outcome, what stops it from probing deeper to find statements from a previous campaign, or from a previous business conference, or from college?").

143. Int' Refugee, 857 F.3d at 598 (observing that courts regularly rely "on principles of 'common sense'... to cull the relevant context surrounding the challenged action," and determine which proffered evidence is reliable and of sufficient probative value) (quoting McCreary Cty. v. ACLU of Ky., 545 U.S. 844, 866 (2005)).

144. Id. at 598-99 ("The campaign statements here are probative of purpose because they are closely related in time, attributable to the primary decisionmaker, and specific and easily connected to the challenged action."); see also Glassroth v. Moore, 335 F.3d 1282,1297 (11th Cir. 2003) (reviewing an elected judge's campaign materials that proclaimed him the "Ten Commandment's Judge" as part of its inquiry into the constitutionality of a Ten Commandments display he installed); Village of Arlington Heights v. Metro. 
lington Heights factors exist exactly for this purpose. Under Arlington Heights, a "historical background" and "specific sequence of events" comprised of contemporaneous statements of animus towards Muslims in the weeks preceding an executive order affecting almost exclusively Muslims would be more probative of intent than a "historical context" and "specific sequence of events" consisting of racially and religiously discriminatory statements made by the same elected official twenty-five years prior. ${ }^{145}$

In short, Judge Kozinski's slippery slope argument overstates the concern. No, judges should not consider any and all scandalous tidbits or "campaign skeletons" in a politician's closets as equally relevant in the discriminatory intent analysis. ${ }^{146} \mathrm{But}$ nothing suggests that any judge would. And to the extent a judge finds he has "no sense of how to weigh" a set of campaign statements, the Arlington Heights factors exist precisely to ground the analysis. ${ }^{147}$ Courts should not be prevented from considering direct, incontrovertible campaign evidence of discriminatory intent out of an unrealized fear that doing so will cause courts to open the floodgates for all past statements. ${ }^{148}$

The dissenting judges in Washington $v$. Trump and Int'l Refugee also warn that a judicial practice of searching for prohibited motives in the things political candidates and government officials say to various public audiences will lead to an endless game of gotcha, in which plaintiffs Google the statements of candidates and officials in search of incautious remarks that can be used in litigation. ${ }^{149}$ But this worry seems vastly exaggerated. Courts con-

Hous. Dev. Corp., 429 U.S. 252, 265-68 (1977) (In the equal protection context, "[w]hen there is $]$ proof that a discriminatory purpose has been a motivating factor in the decision," a court may consider "contemporary statements by members of the decisionmaking body.").

145. See Arlington Heights, 429 U.S. at 267; Lydia O'Connor \& Daniel Marans, Here Are 16 Examples of Donald Trump Being Racist, Huffington Post (Feb. 16, 2017, 1:12 PM), https://www.huffingtonpost.com/entry/president-donald-trump-racist-examples_us_5 $84 f 2$ ccae4b0bd9c3dfe5566 (detailing first-person accounts from the 1990s in which Trump regularly forced African American employees off the floor of his Atlantic City casino, disparaged these employees as "lazy," and claimed that "it's probably not [their] fault because laziness is a trait in blacks. It really is, I believe that. It's not anything they can control.").

146. Washington v. Trump, 858 F.3d at 1174 (Kozinski, J., dissenting).

147. See id. at 1173.

148. Cf. Brief for Appellants at 51, Hawaii v. Trump, 859 F.3d 741 (11th Cir. 2017) (No. 17-15589) (questioning how courts will be able to "wrestle with intractable questions, including the level of generality at which a statement must be made, by whom, and how long after its utterance the statement remains probative"); Kontorovich, supra note 104.

149. Washington v. Trump, 858 F.3d at 1174 (Kozinski, J., dissenting) ("We'll quest 
fronting claims of discriminatory motive give the government the benefit of the doubt: judges are not going to deem government actions unconstitutional just because something somebody said might be interpreted as biased. Indeed, most courts considering the weight of "extra-official" political statements have done so to support the stated position of the government rather than undermine it. ${ }^{150}$

Moreover, enacting any per se restriction against the type of evidence a plaintiff alleging unconstitutional discriminatory purpose can marshal unfairly ignores the already nearinsurmountable burden these plaintiffs face. ${ }^{151}$ Proving any mens rea element is inherently a difficult task, one which is compounded when a plaintiff must attribute the most culpable state of mind (intent) to guarded public officials. ${ }^{152}$ And even if the plaintiff meets her evidentiary burden and proves discriminatory intent, the government may then present evidence that the challenged action was nonetheless necessary and narrowly tailored to achieve a compelling end. ${ }^{153}$

Given the post-Davis reality that few constitutional challenges based on an impermissible discriminatory purpose will ever survive because clear evidence of intent is so often lacking, courts

aimlessly for true intentions across a sea of insults and hyperbole. It will be (as it were) a huge, total disaster."); Int'l Refugee, 857 F.3d at 650 (Niemeyer, J., dissenting) ("The danger of the majority's new rule is that it will enable any court to justify its decision to strike down any executive action with which it disagrees. It need only find one statement that contradicts the stated reasons for a subsequent executive action and thereby pronounce that reasons for the executive action are a pretext.").

150. See Shaw, supra note 109 (manuscript at 48) (noting that in cases considering the importance of presidential speech on a challenged action, that "speech is used to support, rather than to undermine, a president's position"); see, e.g., San Francisco Arts \& Athletics, Inc. v. U.S. Olympic Comm., 483 U.S. 522, 545 n.27 (1987).

151. See Reva B. Siegel, "The Rule of Love": Wife Beating as Prerogative and Privacy, 105 YALE L.J. 2117, 2189 (1996) (asserting that, in a post-Davis world, plaintiffs must show "a state of mind akin to malice" to prove discriminatory intent).

152. See Primus, supra note 91 ("ח] hardly seems fair to tell people who allege their rights have been violated that they can show unconstitutional motives only on the basis of what is contained within official policy announcements and not with evidence of what the policymaking officials have said elsewhere. Even in this Administration, senior officials implementing discriminatory policies usually know better than to write things like 'We are intent on preventing Muslims from coming into the country' into the text of executive orders themselves.").

153. See Pryor v. NCAA, 288 F.3d 548, 562 (3d Cir. 2002) ("Once a plaintiff establishes a discriminatory purpose based on race, the decisionmaker must come forward and try to show that the policy or rule at issue survives strict scrutiny, i.e., that it had a compelling interest in using a race-based classification and this classification is narrowly tailored to achieve that compelling interest."). 
should not further foreclose the possibility of using evidence in the rare case where it exists in abundance. Indeed, "[w] hat is unusual about the present case is that Trump's statements were so clearly biased and so brazenly made, so much so that giving him the benefit of the doubt would amount to willful disregard of the obvious." 154 As the majority in International Refugee opined:

Just as the reasonable observer's "world is not made brand new every morning," . . nor are we able to awake without the vivid memory of [Trump's] statements. We cannot shut our eyes to such evidence when it stares us in the face, for "there's none so blind as they that won't see." ... If and when future courts are confronted with campaign or other statements proffered as evidence of governmental purpose, those courts must similarly determine, on a case-by-case basis, whether such statements are probative evidence of governmental purpose. ${ }^{155}$

\section{The Campaign Speech Straitjacket Argument}

Finally, critics of reviewing campaign rhetoric to divine intent worry that, "[e]ven if a politician's past statements were utterly clear and consistent, using them to yield a specific constitutional violation would suggest an absurd result-namely, that the policies of an elected official can be forever held hostage by the unguarded declarations of a candidate." ${ }^{56}$ In other words, would Trump be "automatically disbarred, from the moment of his inauguration, of exercising certain presidential powers, not because of his actions as president, but because of who he is-that is, how he won the presidency"? 157

In short, no. This concern, while legitimate, again seeks a per se ban on all types of campaign evidence when the concern is one

154. Primus, supra note 91 ("Imagine, by analogy, that the police chief in Washington $v$. Davis had said, on camera and in front of a large public audience, 'I want the Department to use a written test that weeds out black applicants as part of our promotions process.' . . . If the Chief had made that statement, it would obviously be relevant to the question whether the Department's motivation for giving the test were discriminatory."); see Intl Refugee, 857 F.3d at 600 ("[T] evant and probative statements of government purpose at all.").

155. Int'l Refugee, 857 F.3d at 599 (citations omitted).

156. Washington v. Trump, 858 F.3d 1168, 1174 (9th Cir. 2017) (Kozinski, J., dissenting) ("If a court were to find that campaign skeletons prevented an official from pursuing otherwise constitutional policies, what could he do to cure the defect? Could he stand up and recant it all ('just kidding!') and try again? Or would we also need a court to police the sincerity of that mea culpa-piercing into the public official's 'heart of hearts' to divine whether he really changed his mind, just as the Supreme Court has warned us not to?').

157. Kontorovich, supra note 104. 
of degrees. As with all discriminatory intent cases, the passage of time matters. ${ }^{158}$ Those statements made closer in time to the challenged action will have inherently greater evidentiary weight than older statements. Again, this maxim of evidence law is true of all cases-not just equal protection challenges or cases involving campaign statements.

Moreover, intervening statements of contradictory intent or recantation of old discriminatory motives will, at a minimum, tend towards a finding that any previously impermissible motivations have disappeared. ${ }^{159}$ Indeed, in the case of the executive orders,

if the second enactment [was] adopted for pure rather than invidious reasons, it is a qualitatively different enactment insofar as motive, and the way the polity understands it, is an essential part of a law: Justice Holmes once reminded that even a dog knows the difference between being kicked and being tripped over. ${ }^{160}$

As with any evidentiary analysis, there appears no reason why older statements of intent should "stick" with a politician when superseded by more contemporaneous evidence of contrary intent. ${ }^{161}$ Similarly, when a series of campaign statements, made repeatedly over time and immediately preceding enactment of a challenged government action are consistently discriminatory, that record should in fact "stick" with the politician. ${ }^{162}$ In McCreary, where the Court was reviewing a third attempt to create a courthouse display including the Ten Commandments after two prior displays had been deemed unconstitutional, the Court held that its review was not limited to the "latest news about the last in a series of governmental actions" because "the world is not made brand new every morning." 163 Indeed, "reasonable observers

158. See Village of Arlington Heights v. Metro. Hous. Dev. Corp., 429 U.S. 252, 269-70 (1977) (emphasizing the importance of the specific sequence of events leading up to the challenged action); Int'l Refugee, 857 F.3d at 599 (discussing the importance of statements made close in time to the challenged action); Glassroth v. Moore, 335 F.3d 1282, 1286 (11th Cir. 2003) (considering statements made by Chief Justice Moore at the unveiling of the Ten Commandments monument).

159. See Kitrosser, supra note 112 ("A stray bigoted statement by a legislator or executive is unlikely to persuade a court that a measure is discriminatory in the face of ample evidence that it was directed toward, and serves a legitimate, non-discriminatory interest. ... And such inconsistency itself is a factor that courts can and should consider . ...").

160. Amar \& Brownstein, supra note 17.

161. See Segal, supra note 4.

162. See id.

163. See McCreary Cty. v. ACLU of Ky., 545 U.S. 844, 850, 854-56, 866 (2005); see also Jonathan Taylor, The World Is Not Made Brand New Every Morning, TAKE CARE (Mar. 20, 2017), https:// takecareblog.com/blog/the-world-is-not-made-brand-new-every-morning (cri- 
have reasonable memories," and to impose a limitation that factfinders can only consider the most recent public statement would render a court "an absentminded objective observer, not one presumed to be familiar with the history of the government's actions and competent to learn what history has to show." 164

The executive orders themselves prove the danger of such a bright-line rule. While facially neutral, the overwhelming evidence points to a discriminatory motive by the Trump Administration to exclude at least some subset of Muslims from the country on the basis of their religious affiliation. ${ }^{165}$ This evidence post-dates the campaign and extends well into the Trump presidency. ${ }^{166}$ Have these consistent, unambiguous statements of intent really been supplanted by more recent statements by the President's Justice Department articulating non-discriminatory, post-hoc justifications for the executive orders in court filings? Certainly not.

\section{Conclusion}

Courts and commentators are right to express concern about the probative value of campaign statements in assessing discriminatory intent, at least relative to the probative value of official legislative history, early document drafts, or other official governmental records. But a less than compelling piece of evidence is not and should not be rendered inadmissible solely because it is not the "best" possible evidence. Such a rule would upend basic evidence rules and ignore the rare occasion where campaign statements may shed just as much light on a politician's true motives as any carefully scrubbed official document.

tiquing Judge Kozinski's dissent in Washington $v$. Trump).

164. McCreary, 545 U.S. at 866.

165. See supra text accompanying notes 97, 121; Patel, supra note 97 ("When signing the [executive order], Trump read out its title 'Protecting the Nation from Foreign Terrorist Entry into the United States,' looked up and said 'We all know what [it] means .....').

166. See Daniel Burke, Trump Says US Will Prioritize Christian Refugees, CNN (Jan. 30, 2017, 11:28 AM), http://www.cnn.com/2017/01/27/politics/trump-christian-refugees/ index.html (describing Trump's interview with the Christian Broadcasting Network hours before signing the first executive order, in which he stated that the purpose of the order was to prioritize Christian refugees who had been "horribly treated" in the seven desig. nated countries); Jeremy Diamond, Trump Rails Against Court Ruling Blocking Travel Ban, CNN (Mar. 15, 2017, 9:38 PM), http://www.cnn.com/2017/03/15/politics/donald-trump -travel-ban-judge-ruling/index.html (quoting Trump's description of the second executive order as a "watered-down version of the first order"). 


\section{B. Normative Arguments Against Campaign Rhetoric Intent Analysis}

Setting aside evidentiary concerns, at least three normative arguments have been articulated against the use of campaign rhetoric in discriminatory intent analysis irrespective of that rhetoric's probative value. For this set of arguments, one may concede that a given campaign statement might present persuasive evidence of discriminatory intent but nevertheless caution against considering it in order to protect a more important legal or policy principle. These arguments are considered below.

\section{To "Take Care": The Oath of Office Transformation Argument}

A central argument advanced by critics of considering campaign speech distinguishes between campaign speech and "elected official" speech to assert that candidates are private citizens who have not yet taken an oath to "preserve, protect and defend the Constitution," and therefore are not bound to "take Care that the Laws be faithfully executed." 167 Because statements by private persons cannot reveal "the government's ostensible object," 168 these private communications "cannot be attributed to any government actor" to impute an improper purpose to government action. ${ }^{169}$ Then-candidate Trump "was, in this sense, a legally differently obligated person. His policies and their relation to the Constitution would presumably be affected by his oaththat is why the Constitution requires it."170

167. See U.S. ConsT. art. $11, \S 1$, cl. 8 ; id. art. 11, §3; Kontorovich, supra note 104.

168. McCreary, 545 U.S. at 860 .

169. See Glassman v. Arlington Cty., 628 F.3d 140, 147 (4th Cir. 2010); see also Republican Party of Minn. v. White, 536 U.S. 765, 780 (2002) (cautioning against use of statements made without the benefit of advice from an as-yet-unformed administration, and which by definition cannot bind elected officials who later conclude that a different course is warranted); Weinbaum v. City of Las Cruces, 541 F.3d 1017, 1031 (10th Cir. 2008); Modrovich v. Allegheny Cty., 385 F.3d 397, 411-12 (3d Cir. 2004).

170. Kontorovich, supra note 104; see also Brief for Appellants at 51, Int'l Refugee Assistance Project v. Trump, 857 F.3d 554 (4th Cir. 2017) (No. 17-1351) ("Virtually all of the President's statements on which the district court relied were made before he assumed office-before he took the prescribed oath to 'preserve, protect and defend the Constitution'. Taking that oath marks a profound transition from private life to the Nation's highest public office, and manifests the singular responsibility and independent authority to protect the welfare of the Nation that the Constitution necessarily reposes in the Office of the President." (quoting U.S. CONST. art. II, § 1, cl. 8 (citation omitted))). 
This argument has some intuitive formalistic appeal. A private citizen candidate does not yet have any formal obligation to protect the Constitution, and therefore cannot violate the Constitution in any formal decision-making capacity. But this argument misses the point of discriminatory intent analysis. This analysis considers not whether an official action, standing alone, violates the Constitution, but whether the government official's intent makes it so. Although no action taken by a private citizen candidate can violate the faithful execution clause of the Constitution, the motives of a private citizen candidate can indeed inform the analysis of whether that candidate's post-oath actions were impermissibly motivated by discriminatory motive..$^{171}$

Notably, in Glassroth the Eleventh Circuit considered statements made by Chief Justice Moore before securing election to that position, such as a campaign promise to install the Ten Commandments in the state courthouse, as well as campaign materials issued by members of his campaign committee. ${ }^{172}$ Because the state chief justice was the ultimate decision maker, and his campaign committee's statements were fairly attributable to him, such material was appropriately considered in assessing purpose under the Establishment Clause. ${ }^{173}$ "Likewise, all of the public statements at issue here are fairly attributable to President Trump, the government decisionmaker for the Second Executive Order, because they were made by President Trump himself, whether during the campaign or as President . . . "174

A bright-line rule distinguishing between the campaigning politician and the elected official also fails as a practical matter because "[e]lected officials are always at least in part in campaign mode." 175 Indeed, a candidate campaigning for office "is often an incumbent whose campaign and 'official' statements are inherent-

171. See Int'l Refugee Assistance Project v. Trump, 241 F. Supp. 3d 539, 561 (D. Md. 2017) ("Although statements must be fairly 'attributed to [a] government actor,' . . . Defendants have cited no authority concluding that a court assessing purpose under the Establishment Clause may consider only statements made by government employees at the time that they were government employees. Simply because a decisionmaker made the statements during a campaign does not wipe them from the 'reasonable memory' of a 'reasonable observer.") (first quoting Glassman, 628 F.3d at 147; then quoting McCreary, 545 U.S. at 866).

172. Glassroth v. Moore, 335 F.3d 1282, 1285 (11th Cir. 2003).

173. See id. at 1285, 1296; see also Glassman, 628 F.3d at 147.

174. Int'l Refugee, 241 F. Supp. 3d at 561.

175. Amar \& Brownstein, supra note 17. 
ly intertwined." 176 It would be impossible to articulate "a clear rule about what evidence of invidious intent will be inadmissible campaign rhetoric and what may be considered to be probative in the adjudication of constitutional claims." 177 At what point is a sitting senator or President announcing official policy prescriptions and at what point is she wearing the robe of the "poor shlub" just trying to get elected? 178 A bright-line rule based on an unworkable distinction is neither good law nor good logic.

Moreover, a candidate's promises are relevant to inform the electorate of her views of the Constitution generally and whether she believes her policies are consistent with her obligation to "faithfully execute" the laws specifically. In other words, a politician may sincerely believe a particular law or regulation is constitutionally permissible, only to be corrected by the coordinate judicial branch. The same may very well be true for a law or regulation deemed impermissibly discriminatory. A politician, whether candidate or elected official, may sincerely but incorrectly believe that the Constitution permits certain discriminatory state action. In that case, the so-called oath of office transformation is irrelevant because the candidate-turned-elected official maintained his discriminatory intent throughout and was later informed that his motives were constitutionally impermissible.

\section{The Freedom of Political Speech Argument}

The direst warning against heading down the "evidentiary snark hunt" 179 of mining campaign records for discriminatory intent is that it "will chill campaign speech," presumably by curtailing candidates' freedom to say whatever they want without fear of litigation reprisal upon taking office. ${ }^{180}$ As the dissent argued in International Refugee:

176. Id. (A politician "has a dual audience; the government actors he is trying to influence to secure adoption of a regulation and the constituency who elected him whose support will be necessary if he is to stay in office.").

177. Id.

178. Indeed, increasing focus in the media on holding elected officials to account for their campaign promises suggests campaign statements may be more "intertwined" with the work of elected officials than ever before. Tracking Politicians' Promises, POLITIFACT, http://www.politifact.com/truth-o-meter/promises/ (last visited Nov. 15, 2017).

179. Washington v. Trump, 858 F.3d 1168, 1173 (9th Cir. 2017) (Kozinski, J., dissenting).

180. Id. 
[Even considering campaign statements] would by itself chill political speech directed at voters seeking to make their election decision. It is hard to imagine a greater or more direct chill on campaign speech than the knowledge that any statement made may be used later to support the inference of some nefarious intent when official actions are inevitably subjected to legal challenges. ${ }^{181}$

Other courts have refused to consider campaign speech for these exact reasons, in at least some circumstances. For example, in Phelps $v$. Hamilton, the Tenth Circuit declined to consider a district attorney's campaign statements to show that a prosecution commenced a few days after he took office was "bad faith or harassment," because to do so would "chill political debate during campaigns" and undermine the political process for selecting prosecutors. ${ }^{182}$

This argument merits consideration because our most basic free speech principles have their "fullest and most urgent application precisely to the conduct of campaigns for political office."183 But the special nature of campaign speech does not make it "less relevant than other presidential statements. If anything, the opposite is true." 184

For example, critics of considering campaign statements assert that such statements are intended to convey a message to voters rather than articulate any particular legal policy. ${ }^{185}$ But in the First Amendment context, those messages make a legal difference. As Judge Derrick Watson explained in his decision enjoining the second executive order, the Establishment Clause prohibits government action that "sends a message" favoring one religion over another. ${ }^{186}$ Immediately following that decision, President Trump confessed that he wanted to "go back to the first [Executive Order] and go all the way." 187 "As messages go, [then-

181. Int'l Refugee Assistance Project v. Trump, 857 F.3d 554, 651 (4th Cir. 2017) (Niemeyer, J., dissenting).

182. 59 F.3d 1058, 1068 (10th Cir. 1995).

183. McCutcheon v. Fed. Election Comm'n, 572 U.S. _, _, 134 S. Ct. 1434, 1441 (2014) (quoting Monitor Patriot Co. v. Roy, 401 U.S. 265, 272 (1971)); see also Segal, supra note 4 ("It's true that campaign statements deserve special consideration.").

184. Segal, supra note 4.

185. See Toobin, supra note 13; cf. Segal, supra note 4 ("[C]ampaign statements often send the strongest messages to the public.").

186. Hawaii v. Trump, 241 F. Supp. 3d 1119, 1132, 1140 (D. Haw. 2017).

187. Bob Van Boris \& Erik Larson, Trump on Travel Ban Ruling: "Go Back to the First One," BLOOMBERG (Mar. 15, 2017), https://www.bloomberg.com/news/articles/2017-03-16/ trump-on-travel-ban-ruling-go-back-to-the-first-one. 
candidate] Trump's campaign pledge to ban Muslims, and his reaffirmation of that pledge as President, speak far more loudly than any post-hoc memo claiming that the ban is really about national security."188

Moreover, " $[t]$ o the extent that [judicial] review chills campaign promises to condemn and exclude entire religious groups, ... that [is] a welcome restraint." 189 Put another way, the concern of judges and scholars about threats to democracy from chilling campaign speech seems backwards, because the true threat lies not in discouraging politicians from making bigoted statements, but in giving candidates "a free pass for discriminatory campaign statements." 190 If courts set a precedent allowing candidates to make bigoted statements with impunity, the road will widen for divisive politicians to ride a prejudiced wave to electoral victory without facing consequences when they take prejudiced official government action.

This problem is neither new nor unique to campaign speech, but remains a central problem with Davis and its progeny. The courts have signaled to government actors how to construct statutes and engage in action in a way that will avoid an equal protection problem. Even if a government official intends to harm a racial group, she can act in a facially neutral manner and leave few circumstantial indicators of impermissible intent. ${ }^{191} \mathrm{Or}$, if a legislature intends a disparate impact, it will make sure to write a facially neutral statute and exclude any evidence of impermissible intent from the legislative history. So long as negative consequences of government action do not have obvious indicators of subjective discriminatory intent, the government can explain a

188. Segal, supra note 4.

189. Int'l Refugee Assistance Project v. Trump, 857 F.3d 554, 600 (4th Cir. 3017).

190. Segal, supra note 4 ("Far from chilling speech if we hold candidates to their words, we should be concerned about facilitating discrimination by exempting entire categories of political speech from ordinary methods of proving intent. That's because what is at stake in the travel ban litigation is not just whether President Trump will be held accountable for his past campaign statements, but also whether politicians in future campaigns will have to worry that promising unconstitutional actions will come back to bite them in court when, as public officials, they seek to make good on those promises.").

191. Primus, supra note 91 ("The rule that constitutionality depends on motive usually favors the government in civil-liberties cases, because it is usually hard to prove that the government has acted for bigoted reasons. For half a century, governmental actions with clearly discriminatory motives have been rare-and in cases where the government's motive might indeed be discriminatory, it is typically hard to find proof, because most government officials know better than to go around saying "This is a law targeted at blacks/women/gays/Muslims."'). 
harmful effect by reference to a different permissible purpose, and any equal protection challenge is unlikely to prevail. ${ }^{192}$

\section{ARLINGTON HEIGHTS REDUX: EVIDENTIARY CONSIDERATIONS FOR CAMPAIGN STATEMENTS}

The Burger Court's shift from disparate impact to discriminatory intent in Davis simultaneously narrowed litigants' ability to successfully challenge government action and broadened (at least theoretically) the types of evidence litigants could present to prove discriminatory purpose. Arlington Heights sought to place principled limits on the scope of permissible evidence as reflected in the six-factor test discussed above. ${ }^{193}$ Notwithstanding courts' reluctance to consider campaign statements as a part of this permissible evidentiary universe, such statements clearly fall within at least three of Arlington Heights' six factors:

(1) The historical background of the decision: Statements made by politicians regarding a proposed government action certainly form an important part of the historical background of that action;

(2) The specific sequence of events leading up to the challenged decision: As the executive orders litigations demonstrate, campaign statements can prove critical in establishing a compelling sequence of events leading up to the decision; and

(3) The legislative or administrative history of the decision: While campaign statements per se are not part of the official legislative record, the blurred lines between an elected official acting in an official capacity and an elected official perpetually in campaign mode make at least certain types of campaign statements relevant to provide context for the official legislative or administrative history. ${ }^{194}$

Beyond confirming the evidentiary relevance of campaign speech as admissible to the discriminatory intent analysis as de-

192. Ian Samuel \& Leah Litman, No Peeking? Korematsu and Judicial Credulity, TAKE CARE (Mar. 22, 2017), https://takecareblog.com/blog/no-peeking-korematsu-and-judicialcredulity ("In many ways, the travel-ban litigation is the easy case, because the statements of motive are staring everyone in the face ....").

193. See Village of Arlington Heights v. Metro. Hous. Dev. Corp., 429 U.S. 252, 267-68 (1977).

194. See id.; see Amar \& Brownstein, supra note 17. 
fined by Arlington Heights, this section highlights some specific, objective considerations for courts to determine the probative value of this evidence. In particular, the size of the decision-making body, the nature of the constitutional claim, and whether the action implicates separation of powers concerns bear heavily on the analysis of whether and to what extent campaign statements reflect impermissible animus. ${ }^{195}$ But, as with misguided attempts to create a bright-line ban on consideration of campaign statements, courts should interpret these objective factors flexibly and on a case-by-case basis and resist the urge to create rigid standards based on any of these three considerations.

\section{A. The Size of the Decision-Making Body}

Unsurprisingly, it is more difficult to establish the underlying motives of ten county commissioners or one hundred senators than it is of one mayor, governor, or President. Just as one individual actor may have mixed motives for taking a particular action, many individual actors likely present as many disparate motives as there are individuals responsible for the action itself. This reality yields "[y]et another reason proffered for refraining from motive analysis [as] the motive of many legislative bodies is hard to discern-in Congress, there may be hundreds of motives of hundreds of legislators in enacting a particular law."196 As the Court explained in Hunter $v$. Underwood, "the difficulties in determining the actual motivations" of a governing institutional body increase substantially when a claim is brought against the U.S. Congress as opposed to a county board of commissioners. ${ }^{197}$

For example, the Court in United States v. O'Brien "downplayed the idea that an act of Congress could be struck down because of the intent of some legislators to enact it for the purpose of suppressing protected speech." 198 In contrast, the Court found

195. See Amar \& Brownstein, supra note 17 ("In short, courts appear to weave their way through many complex factors in evaluating claims based on invidious or impermissible motives. ... [T] he nature of the constitutional claim, the size of the decision-making body, and the persuasiveness of the extrinsic evidence of impermissible motive will all be considered, with different factors controlling the Court's analysis in various cases.").

196. Id.

197. 471 U.S. 222,228 (1985).

198. Amar \& Brownstein, supra note 17; United States v. O'Brien, 391 U.S. 367, 38384 (1968) ("Inquiries into congressional motives or purposes are a hazardous matter. When the issue is simply the interpretation of legislation, the Court will look to statements by legislators for guidance as to the purpose of the legislature, because the benefit 
in Mt. Healthy City School District v. Doyle that a teacher could assert a valid free speech claim challenging the school board's decision not to rehire him if the teacher could show the board was punishing him for protected speech in which he had engaged. ${ }^{199}$ The Court reasoned that the motivations of a small, insulated school board would likely be much easier to determine than that of a Congress divided into constituencies across the country. ${ }^{200}$

But courts have not and should not apply this factor rigidly. In Hunter, for instance, the Court struck down, on equal protection grounds, a provision of the 1901 Alabama Constitution denying the right to vote to any person convicted of a crime involving moral turpitude. ${ }^{201}$ While facially neutral, the Court relied on the historical background and legislative record to find that the allwhite state constitutional convention adopting the provision did so with the intent of disenfranchising black residents in particular. ${ }^{202}$ The large size of the convention did not insulate it from an equal protection challenge given the strength of the historical evidence establishing the invidious motivation of the convention participants. ${ }^{203}$

Likewise, uncovering the motive behind an executive actionwhich seemingly involves consideration of only one actor's "heart of hearts"- may prove more difficult than it seems. Referring to the executive orders litigations, Amar and Brownstein contend that, because "the authority to issue an executive order rests with one person alone, ... struggling to determine the intent of a large body is not a problem here." 204

to sound decision-making in this circumstance is thought sufficient to risk the possibility of misreading Congress' purpose. It is entirely a different matter when we are asked to void a statute that is, under well-settled criteria, constitutional on its face, on the basis of what fewer than a handful of Congressmen said about it. What motivates one legislator to make a speech about a statute is not necessarily what motivates scores of others to enact it, and the stakes are sufficiently high for us to eschew guesswork." (footnote omitted)).

199. 429 U.S. $274,283-84,287$.

200. See id. at 280 .

201. Hunter, 471 U.S. at $223,233$.

202. Id. at $228-29$.

203. Id. ("[T] he sort of difficulties of which the Court spoke in O'Brien do not obtain in this case. Although understandably no 'eyewitnesses' to the 1901 proceedings testified, testimony and opinions of historians were offered and received without objection. These showed that the Alabama Constitutional Convention of 1901 was part of a movement that swept the post-Reconstruction South to disenfranchise blacks.").

204. Amar \& Brownstein, supra note 17. 
But is the President's motivation the only relevant one, even if he is the ultimate decision maker? What about the motivations of the advisors and cabinet officials involved in the development and crafting of a policy enactment? Is it "worth nothing that the executive order blocked by the courts was jointly announced by the Attorney General and the Secretaries of State and Homeland Security, who asserted that its issuance was in the national interest (and not intended to discriminate against Muslims)"?205 Should these opinions be considered in the discriminatory intent analysis? Yes and no.

Just as a campaign surrogate's brash statements may provide a window into the true motivations of a more measured political candidate, a subordinate government officer charged with crafting policy may also make statements indicative of the executive's intent. Therefore, these statements may be considered relevant to the analysis but ought to be discounted accordingly as inherently less probative than statements from the decision maker himself.

But while statements of other closely connected non-decision makers may be relevant to determining the decision maker's intent, it is important to note that the intent of these non-decision makers remains irrelevant and ought not to be considered. In other words, the benign (or not so benign) motivations of public officials, such as Jeff Sessions or John Kelly, are not at all relevant to discerning the purpose of a presidential executive order, because neither the Attorney General nor the Secretary of Homeland Security are authorized to issue a presidential executive order. Even if a plaintiff asserted that the President delegated all authority for crafting a policy to a subordinate and merely adopted whatever action was proposed, such an argument still would require a showing that the motivations of the subordinate officer were synonymous with that of the executive.

\section{B. The Nature of the Constitutional Claim}

As discussed above, a court's analysis of governmental motive may alter slightly depending on whether the constitutional challenge raises a Fourteenth Amendment equal protection claim, a First Amendment free exercise claim, or a First Amendment Es-

205. Toobin, supra note 13 ("In the absence of some extraordinary circumstances not evident to me here, those views should be persuasive to a trial-court judge."). 
tablishment Clause claim. All three types of claims require some showing of intent, but unlike equal protection and free exercise claims, "the Court in several Establishment Clause rulings has explicitly required that government's motive be either secular, or at the very least not a desire to favor some sects over others." 206 Indeed, there is probably "no area of constitutional law in which direct inquiry into motive has been more accepted than equal protection jurisprudence adjudicating claims against invidious discrimination." 207

This doctrinal fact should have no bearing on whether to consider campaign speech as part of the discriminatory intent analysis. As discussed throughout, campaign speech should be considered anytime a motive forms an element of the constitutional claim. But it should affect how such evidence is considered. The subtle shift in burdens between Establishment Clause and Equal Protection Clause challenges ought to also be reflected in how courts consider and treat campaign speech connected to such challenges. For example, if a plaintiff bears the burden of establishing an impermissible racial discriminatory motive under the Equal Protection Clause, the plaintiff must also bear the burden of establishing how certain pre-election statements prove such motive. By contrast, if the government bears an affirmative responsibility to establish a secular motive for its action, it should also bear the responsibility to rebut prima facie evidence of improper motive.

\section{Deference and Separation of Powers Concerns}

In addition to the nature of the constitutional claim, courts should and do consider the nature of the governmental interest at stake and whether those interests implicate separation of powers concerns that require courts to provide greater latitude for otherwise constitutionally suspect actions of the political branches. Importantly, however, whether greater deference is owed to the political branches in a particular case should not determine whether campaign speech should be considered at all in the discriminatory intent analysis, but only whether such evidence is sufficient to meet the appropriate legal standard.

206. Amar \& Brownstein, supra note 17.

207. Id. 
For example, a government classification made on the basis of race normally would automatically trigger strict scrutiny review and require the government to demonstrate both a compelling need for the action and that the action was the most narrowly tailored means of achieving that need. ${ }^{208}$ Likewise, sufficient evidence of a racially discriminatory motive behind a facially neutral law would trigger strict scrutiny review. ${ }^{209}$

In the immigration context, however, courts have long deferred to the actions of the political branches even where substantial evidence existed of racially or religiously discriminatory motive. ${ }^{210}$ This doctrine of deference-known as "plenary power"-traces back to the infamous Chinese Exclusion Case, in which the Court upheld the exclusion of a Chinese national in accordance with an act of Congress all but explicitly motivated by contempt for Chinese individuals. ${ }^{211}$ In its decision, the Court upheld the exclusion against a constitutional equal protection challenge, finding that immigration decisions by the "legislative department" to exclude aliens are "conclusive upon the judiciary."212 According to the Court, the propriety of immigration decisions and their impact on foreign affairs with other countries "are not questions for judicial determination. If there be any just ground of complaint on the part of China, it must be made to the political department of our government, which is alone competent to act upon the subject."213

The Court has since held that the government must at least offer a "facially legitimate and bona fide" 214 reason for a challenged immigration action and has indicated in dicta that the immigration power is "subject to important constitutional limitations."215 But in reality, "the Supreme Court [has never] struck down an

208. Grutter v. Bollinger, 539 U.S. 306, 326-27 (2003).

209. See Village of Arlington Heights v. Metro. Hous. Dev. Corp., 429 U.S. 252, 266-70 (1977).

210. See, e.g., David A. Martin, Why Immigration's Plenary Power Doctrine Endures, 68 OKLA. L. REV. 29, 30-31 (2015) (summarizing history of judicial deference in immigration context); $c f$. Shawn E. Fields, The Unreviewable Executive? National Security and the Limits of Plenary Power, 84 TENN. L. REv. (forthcoming 2017) (manuscript at 2, 4) (on file with Tennessee Law Review) (asserting that the plenary power as once understood has eroded considerably in the last twenty years).

211. See Chae Chan Ping v. United States, 130 U.S. 581, 589, 595-96 (1889).

212. Id. at 606 .

213. Id. at 609.

214. See, e.g., Kleindienst v. Mandel, 408 U.S. 753, 770 (1972).

215. Zadvydas v. Davis, 533 U.S. 678, 695 (2001). 
immigration classification, even ones based on race."216 Indeed, this doctrine of deference has led the Court to "uphold[ with depressing regularity statutes discriminating on the basis of race, sexual orientation, political activity, and sex and birth out-ofwedlock" 217 that would never pass constitutional muster in a nonimmigration context.

With such a consistent history of deference, it is easy for one to assume that "[ $\mathrm{t}]$ he [C]ourt has given the political branches the judicial equivalent of a blank check to regulate immigration as they see fit." 218 The Trump Administration has advanced this absolutist position in its defense of the executive orders, asserting that courts "[c]annot... [r]eview the President's... Executive Order[s]," precisely because "[t]here is . . no basis for the Judiciary to second-guess the President's determinations" in the immigration context. ${ }^{219}$

Relying on this history of deference, courts, commentators, and the Department of Justice have all argued that campaign statements about a proposed immigration action are entirely irrelevant and should never be considered. In its brief before the Fourth Circuit, the Department of Justice argued that thencandidate Trump's "Muslim ban" statements were off limits because, "[p]robing the President's grounds for immigration policies would thrust 'ill equipped' courts into the untenable position of evaluating the 'adequacy' and 'authenticity' of the Executive's reasons underlying its foreign-affairs and national-security judgments." ${ }^{220}$ Likewise, Toobin asserts that campaign statements are

216. Peter J. Spiro, Trump's Anti-Muslim Ban Is Awful. And Constitutional., N.Y. TIMES (Dec. 8, 2015), https://www.nytimes.com/2015/12/10/opinion/trumps-anti-muslimplan-is-awful-and-constitutional.html.

217. Gabriel J. Chin, Is There a Plenary Power Doctrine? A Tentative Apology and Prediction for Our Strange but Unexceptional Constitutional Immigration Law, 14 GEo. IMMIGR. L.J. 257, 257 (2000) ("These decisions, and the statutes they upheld, are inconsistent with fundamental values reflected in domestic constitutional law, yet they continue to constitute the foundation of immigration law.").

218. Spiro, supra note 216.

219. Defendant's Opposition to Plaintiff State of Washington's Motion for Temporary Restraining Order at 21-24, Washington v. Trump, No. C17-0141JLR, 2017 U.S. Dist. LEXIS 16012 (W.D. Wash. Feb. 3, 2017) (Immigration decisions are areas "within the exclusive domain of the political branches of our government. . . It is thus well-established that courts cannot evaluate the President's national security and foreign affairs judgments, especially in the immigration context. ... It is simply not possible for the Court here to evaluate the President's Executive Order without passing judgment on the President's national security and foreign affairs determinations.").

220. Brief for Appellants at 45-46, Int'l Refugee Assistance Project v. Trump, 857 F.3d 
irrelevant in the immigration context because "Presidents should be allowed to receive and accept advice to modify their views without penalty from the courts ... especially ... when it comes to matters of national security." ${ }^{21}$ And in dissent, Judge Bybee opined that consideration of campaign speech constitutes an impermissible "peek behind the curtain. So long as there is one 'facially legitimate and bona fide' reason for the President's actions, our inquiry is at an end." 222

These arguments miss the mark by conflating a court's invocation of a deferential standard of review with a court's right to consider evidence to determine whether the government has met this low standard. Over a century of immigration precedent appears to confirm that the government need only provide a "facially legitimate and bona fide" reason for an immigration action. ${ }^{223}$ But campaign statements can illuminate whether such a facially legitimate and bona fide reason actually exists. Any suggestion that courts cannot consider evidence that a challenged action was illegitimate, irrational, or arbitrary simply because the standard of review is "facially legitimate" or "rational basis" lacks coherence. It is akin to arguing that no standard exists at all. ${ }^{224}$

The majority in International Refugee demonstrated the critical role evidentiary campaign speech can play in probing for a ra-

554 (4th Cir. 2017) (No. 17-1351) ('Under the Constitution's structure and its separation of powers, courts evaluating a presidential policy directive should not second-guess the President's stated purpose by looking beyond the policy's text and operation. The 'presumption of regularity' that attaches to all federal officials' actions . . . applies with the utmost force to the President himself.").

221. Toobin, supra note 13.

222. Washington v. Trump, 858 F.3d 1168, 1183-84 (9th Cir. 2017) (Bybee, J., dissenting) ("The Executive should not have to disclose its 'real' reasons for deeming nationals of a particular country a special threat—or indeed for simply wishing to antagonize a particular foreign country by focusing on that country's nationals-and even it if did disclose them a court would be ill equipped to determine their authenticity and utterly unable to assess their adequacy.").

223. See, e.g., id. at 1179-80.

224. See Samuel \& Litman, supra note 192.

The Trump Administration says these cases mean the courts can never look behind an immigration executive order. On this theory, the courts would have to uphold the executive order even if Trump, upon signing it, had announced, "I do this to make crystal clear that Christianity is America's official religion, and that Islam has no place here." That cannot be right.

David Cole, Judges Shouldn't Ignore What We All Know Trump's Travel Ban Is Really About, WASH. POST (Mar. 22, 2017), https://www.washingtonpost.com/opinions/judges-sh ouldnt-ignore-what-we-all-know-trumps-travel-ban-is-really-about/2017/03/22/4ad23ce 2 -0f 21-11e7-ab07-07d9f521f6b5_story.html?utm_term=.fd13842e73fc. 
tional or facially legitimate motive. The majority noted the Trump Administration had proffered a purportedly bona fide reason for the second executive order-national security. ${ }^{225}$ But this thinly defended reason was belied by the mountain of evidence from the campaign trail, beyond confirming that this reason was anything but bona fide, and that the real reason was anything but legitimate. 226

The Trump Administration's attempt to "use magic words like 'national security"'227 to convert prejudicial motives into benign justifications closely parallels the circumstances surrounding another infamous member of the "anticanon," Korematsu v. United States. ${ }^{228}$ In upholding the conviction of an American of Japanese descent for violating an exclusion order that required him to stay in an internment camp, the Court accepted the government at its word that internment was "deemed necessary because of the presence of an unascertained number of disloyal members" residing in the camps. ${ }^{229}$ The Court declined to consider the compelling and damning evidence of racially discriminatory intent behind the internment camps, instead concluding that it "could not reject" this finding of "the military authorities." 230

225. Int'l Refugee, 857 F.3d at 572 ("The question for this Court, distilled to its essential form, is whether the Constitution ... protects Plaintiffs' right to challenge an Executive Order that in text speaks with vague words of national security, but in context drips with religious intolerance, animus, and discrimination.").

226. Id. at 575-76 (contrasting sworn statements of ten former national security experts that " $[t]$ here is no national security purpose for a total ban on entry for aliens from the [Designated Countries]" with the "backdrop of public statements by the President and his advisors" over the course of the campaign concerning a "Muslim ban").

227. See Segal, supra note 4 .

228. Jamal Greene, The Anticanon, 125 HARV. L. REv. 379, 380 (2011) (arguing that infamous Supreme Court cases like Plessy v. Ferguson and Korematsu v. United States do not "involve bad reasoning, nor are they morally repugnant. . . I argue that anticanonical cases achieve their status through historical happenstance"); see Korematsu v. United States, 323 U.S. 214 (1944).

229. Korematsu, 323 U.S. at 215-16, 218-19.

230. Id. at 219. In a meticulous dissent, Justice Frank Murphy peeked behind the curtain of this national security rationale and detailed overwhelming evidence of racial animus, including "questionable racial and sociological grounds" claiming the Japanese are "given to "emperor worshipping ceremonies," and statements by the commanding general responsible for the Japanese evacuation of the West Coast that "I don't want any of them here" because "[t]here is no way to determine their loyalty" and that the "danger of the Japanese [is] espionage and sabotage." Id. at 236-39, 236 n.2 (Murphy, J., dissenting); see also Samuel \& Litman, supra note 192 ("But the real motivations for these conclusions, Murphy could see, were not expert military judgments but naked racism. And he was able to arrive at this conclusion by doing just what the no-peeking view objects to: looking behind the curtain of the proffered rationale for the exclusion order to see where it came 
Not surprisingly, in 2011, the United States filed a formal "admission of error" acknowledging that the government had misled the Court by refusing to disclose intelligence reports undermining the stated "national security" rationale and other documents confirming the explicitly sectarian motives behind the camps. ${ }^{231}$ If nothing else, the shame of the Korematsu decision should cause judges to think twice before rejecting out of hand consideration of damning campaign statements in the name of judicial deference.

\section{CONCLUSION}

Discerning intent is inherently difficult. In a post-Washington $v$. Davis world, this difficult task falls to plaintiffs hoping to successfully challenge a racially or religiously discriminatory government action. It is "difficult to win cases requiring proof of discriminatory intent precisely because politicians are usually circumspect when they have discriminatory views." 232 It is because of this deliberate obfuscation, and because "legislators and administrators are properly concerned with balancing numerous competing considerations that courts refrain from reviewing the merits of their decisions, absent a showing of arbitrariness or irrationality." 233

But "racial [and religious] discrimination is not just another competing consideration. When there is proof that a discriminatory purpose has been a motivating factor in the decision, this judicial deference is no longer justified." ${ }^{34}$ Given the high stakes of permitting invidious government discrimination and the structurally high burden a plaintiff must meet to prove discrimination, courts can and should follow the roadmap of Arlington Heights and consider evidence of animus in its many forms-in the historical background of the action, the legislative history of the action,

from.").

231. Samuel \& Litman, supra note 192; Confession of Error: The Solicitor General's Mistakes During the Japanese-American Internment Cases, U.S. DEP'T OF JUSTICE (May 20, 2011), https://www.justice.gov/archives/opa/blog/confession-error-solicitor-generals-mis takes-during-japanese-american-internment-cases.

232. Richard L. Hasen, Does the First Amendment Protect Trump's Travel Ban?, SLATE (Mar. 20, 2017, 9:28 AM), http://www.slate.com/articles/news_and_politics/jurisprudence/ 2017/03/the_9th_circuit_s_alex_kozinski_defends_trump_s_travel_ban_on_first_amendme nt.html.

233. Village of Arlington Heights v. Metro. Hous. Dev. Corp., 429 U.S. 252, 265 (1977).

234. Id. at 265-66. 
and the statements of the officials responsible for the action. This includes pre-election campaign statements.

Those who claim broadly that no judge should "peek behind the curtain" to determine intent ignore forty years of precedent. Those who claim narrowly that campaign speech is somehow inherently defective and cannot reliably elucidate intent ignore a court's inherent and most basic ability to weigh and discount, where necessary, the probative value of such evidence. Worse, those who seek a bright-line ban on consideration of campaign speech fail to consider "the rare candidate who speaks his mind, [who tells] us why he wanted to keep Muslims out of the U.S."235 And those who seek to ignore compelling and damning context of animus because that animus has been "laundered" with the pretext of national security risk repeating the mistakes of the Supreme Court's darkest hour in Korematsu.

Politicians certainly do lie. But candidates also tend to keep their promises. If a candidate invites voters to rely on divisive and discriminatory campaign pledges in order to secure electoral victory, he should not be surprised when litigants later rely on those pledges to challenge his constitutionally suspect actions once in office. "Candidates who make these statements are not 'poor shlubs.' They are being held to account for what they say." ${ }^{336}$

235. Hasen, supra note 232 .

236. Id. 